OPEN ACCESS

Edited by:

Shailesh Kumar Patidar,

Central University of Rajasthan, India

Reviewed by:

Leonel Pereira,

University of Coimbra, Portugal

Irina Guschina,

Cardiff University, United Kingdom

*Correspondence:

Avinash Mishra

avinash@csmcri.res.in;

avinashmishra11@rediffmail.com

Specialty section:

This article was submitted to

Marine Biotechnology,

a section of the journal

Frontiers in Marine Science

Received: 12 July 2021

Accepted: 10 September 2021

Published: 05 October 2021

Citation:

Choudhary B, Chauhan OP and

Mishra A (2021) Edible Seaweeds: A Potential Novel Source of Bioactive Metabolites and Nutraceuticals With

Human Health Benefits.

Front. Mar. Sci. 8:740054.

doi: 10.3389/fmars.2021.740054

\section{Edible Seaweeds: A Potential Novel Source of Bioactive Metabolites and Nutraceuticals With Human Health Benefits}

\author{
Babita Choudhary 1,2, O. P. Chauhan ${ }^{3}$ and Avinash Mishra ${ }^{1,2 *}$ \\ ${ }^{1}$ Division of Applied Phycology and Biotechnology, CSIR-Central Salt and Marine Chemicals Research Institute, Bhavnagar, \\ India, ${ }^{2}$ Academy of Scientific and Innovative Research, CSIR, Ghaziabad, India, ${ }^{3}$ DRDO-Defence Food Research \\ Laboratory, Mysore, India
}

There has been an increase in human health concerns, and seaweeds are considered as a potential functional food which can decrease the risk of many diseases, as they contain various bioactive compounds. Seaweeds are of nutritional interest and a rich source of natural bioactive compounds including antioxidants, flavonoids, phenolic compounds, and alkaloids that can be used as an alternative source of food material. Seaweeds contain a high amount of vitamins such as A, D, E, C, and B, and minerals including calcium, potassium, magnesium and iron. Seaweeds containing carrageenan, agar and other polysaccharides not only act as a source of fiber but also can act as prebiotics which may benefit the bacteria present in the large intestine. The lack of technologies to process seaweeds for human consumption at an industrial scale is a serious limitation on growth of the seaweed-based functional foods sector. Seaweeds are one of the most extensively used functional foods, with a long history in Asian countries. Now they are also being explored by many Western and European countries. Evidence from epidemiological research suggests that regular consumption of a marine algae-based diet may boost immunity against a number of diseases including COVID-19 novel virus by angiotensin-I-converting enzyme (ACE) inhibition.

Keywords: antioxidants, bioactive compounds, functional food, nutraceuticals, seaweeds

\section{INTRODUCTION}

In the early twentieth century, it was a common belief that food is needed for body growth only. Recent advancements in food and nutritional research have revolutionized this common belief, and food requirements are shifting toward the role of the diet in promoting human health and avoiding disease (Admassu et al., 2015). There have been significant changes in our food habits, such as the diet in urbanized countries being extremely caloric and rich in sugars and saturated fats, even as complex carbohydrates and dietetic fiber are utilized at low concentrations. These factors are responsible for a decrease in physical activity and increase the probability of many diseases in the population. Over the last few years, foodstuffs have been extensively used to achieve better health; 
our research data on the connection between food components and fitness are at present being used to obtain better quality food (Holdt and Kraan, 2011). In recent years, research attentions have been developed to search for bioactive molecules due to their various health-beneficial effects (Amorim et al., 2012). Bioactive compounds are components that have been obtained from natural or synthetic sources and are assayed for activity in a number of key therapeutic areas. Bioactive compounds possess activity that is good for health, and it has been shown that bioactive food molecules can change the gene expression of a host at cellular level, thereby influencing health (MacArtain et al., 2007). At present, seaweeds have attracted much interest as a natural source of bioactive compounds with a significant role in the development of nutraceuticals. Seaweeds are extremely varied in terms of species, habitat, maturity, environmental conditions, and period of harvesting but they are excellent sources of different nutrients (Tanna and Mishra, 2018a).

A variety of marine algae are used as healthy food and they have been used in pharmaceuticals due to their supposed health benefits. Seaweeds are chlorophyll-containing organisms, a group of multicellular plants known as macroalgae that grow in marine systems (Kharkwal et al., 2012). Traditionally, seaweeds or macroalgae can be classified into three different groups: green algae (Chlorophyta), brown algae (Ochrophyta, Phaeophyceae), and red algae (Rhodophyta). This classification is based on various factors like the chemical nature of photosynthetic storage products, pigmentation, other morphological appearance, and the organization and components of photosynthetic membranes. The chlorophyll content of seaweeds is responsible for their color; green algae contain chlorophyll $\mathrm{a}$ and $\mathrm{b}$ in equal amounts, the same as higher plants, that is responsible for their green color. The color of brown algae is due to xanthophyll and fucoxanthin pigments; these are accessory pigments and mask chlorophylls and other xanthophylls, whereas phycoerythrin and phycocyanin are dominant in red algae, masking the effect of other pigments and providing their red color (Kilınç et al., 2013).

Marine algae are a rich source of several bioactive compounds such as dietary fibers, proteins, minerals, and vitamins; they also contain bioactive substances like polysaccharides, polyphenols, phytochemicals, and polyunsaturated fatty acids with potential therapeutic uses against inflammation, cancer, oxidative stress, allergies, diabetes, thrombosis, obesity, hypertension, lipidemia, and many degenerative diseases (Tanna and Mishra, 2019). These compounds gave seaweeds a higher value in the individual diet as a food component and as pharmaceutical supplements (Namvar et al., 2013). The physiologically active substances of seaweeds are separated into two groups according to differences in their mechanisms: (a) high molecular weight materials which are not absorbed, like dietary fibers, and (b) low molecular weight materials which are absorbed and directly affect human homeostasis (Murata and Nakazoe, 2001). In seaweeds, various environmental factors play a significant role in the production of biological molecules, including temperature, UV radiation exposure, and grazers. These factors are responsible for the variation in biomolecules in the same species (Zenthoefer et al., 2017).

\section{WHY SEAWEED FOR HEALTH AND NUTRACEUTICALS?}

It is predicted that the global population will be virtually 10 billion people by 2050, up from 7.3 billion today (Ehrlich and Harte, 2015). Even the current population does not have enough food for a healthy and active life. To solve this greater food demand, many countries have started to explore alternative food sources including marine bio-resources. Approximately $70 \%$ of the earth's surface is covered by seas and oceans. A broad range of various habitats is provided by the marine environment from which natural sources of diversified products can be derived (Jiménez-Escrig et al., 2012). It has been proved that the marine environment is a rich source of biological and chemical diversity; these marine organisms have high potential as sources of compounds that can be applied in the food industry, cosmetics industry, nutraceutical and pharmaceutical industry, and other industrially important compounds (Tanna and Mishra, 2018b). Seaweeds have considerable environmental appeal because they require neither freshwater nor fertilizer, nor much use of land; they use renewable living resources and are infected by few pests and diseases (Vallinayagam et al., 2009). Seaweeds do not require extra fertilizer to grow and they absorb carbon dioxide from sea runoffs, giving them a carbon-negative footprint. The growth rate of seaweeds is much higher than that of plants and other food sources. Seaweeds can be collected naturally but at this time are increasingly cultivated.

\section{ROLE OF SEAWEEDS IN HUMAN HEALTH}

In living organisms, some molecules are formed during aerobic processes, such as reactive oxygen species (ROS) which are a group of highly reactive molecules including free radicals like 2,2-diphenyl-1-picrylhydrazyl (DPPH), superoxide anion $\left(\mathrm{O}^{2} \bullet\right.$ ) and hydroxyl radicals ( $\mathrm{HO})$, and non-radicals such as singlet oxygen $\left(\mathrm{O}_{2}\right)$ or hydrogen peroxide $\left(\mathrm{H}_{2} \mathrm{O}_{2} \bullet\right.$ ) (Ahn et al., 2007). ROS are identified as a class of reactive species that can easily act in response to a number of molecules in living organisms and are known as a major source of oxidative stress that may cause gene mutation, direct DNA strand breakage, and DNA-DNA or DNA-protein cross links. ROS are one of the main reasons for many kinds of diseases such as cancer, neurodegenerative disease, cataracts, cardiovascular disease, and atherosclerosis (Salar and Dhall, 2010).

Free radicals can be converted into non-radicals to prevent oxidation by donating electron and hydrogen, dissolving generated peroxidation compounds and chelating transition metals (Enrique and Lester, 2002). Antioxidants are used in the human diet to decrease or avoid oxidation in food products, to improve nutritional quality, to delay the formation of toxic oxidation products and thus to increase the life of food. Food industries generally use synthetic antimicrobial compounds such as sodium nitrite, sodium benzoate and sorbic acid, and artificial antioxidants such as butylated hydroxytoluene (BHT), butylated hydroxyanisole (BHA), and tert-butylhydroquinone 
(TBHQ) for improving the quality of food (Shahidi et al., 2005). On the other hand, it has been reported that these synthetic biomolecules are harmful and have carcinogenic effects (Chen et al., 1992). Therefore, progressively more research is being done on natural antioxidants, antimicrobials or antioxidants with significant and various claims for health-promoting properties (Andarwulan et al., 2010).

Plants contain some natural pigments like carotenoids that respond rapidly to these free radicals and reduce the amount of oxidative deterioration, and these compounds increase food value (Fernández-López et al., 2020). Different classes of antioxidants have been reported in different kinds of higher plants (Cai et al., 2004). A number of research reports have revealed seaweed to be a rich source of antioxidant compounds (Tanna et al., 2019). Antioxidant activity has developed into an interesting area under discussion of demanding investigations because of the growing interest in the food and pharmaceutical industries to expand natural bioactive compounds that exhibit considerable health benefits (de Souza et al., 2007).

\section{BIOACTIVE METABOLITES OF SEAWEED ORIGIN}

Research in recent years suggest that seaweeds have been well considered as organisms that have the potential to provide novel biologically active substances and compounds that are necessary for human nutrition and growth; due to these features, marine algae have high economic importance in pharmaceuticals, nutraceuticals and human health (Smit, 2004; Cardozo et al., 2007; MacArtain et al., 2007). A marine system is an extremely competitive environment in which to survive, seaweeds have to make some remarkably diverse compounds by altering their metabolic pathway to develop defense strategies (Cardozo et al., 2007). These diverse compounds are well known as bioactive compounds and their activity has been linked to improving human health by altering the genetic expression of cellular events for decades (MacArtain et al., 2007). Nowadays, seaweeds have become a multi-billion-dollar industry due to their global utilization in pharmaceuticals, nutraceuticals, and cosmetics (Sultana et al., 2012). The biological compounds in seaweeds are also progressively more used in biochemical and medical research (Smit, 2004). In some countries, marine algae, or macroalgae (seaweeds) are used to improve soil fertility to enhance crop productivity because they contain many compounds that have the capacity of stimulate plant growth (Khan et al., 2009).

Of the total volume of marine macroalgae, it is noticeable that more is used in foods as compared to industrial applications, especially in terms of their economic value and weight. In the Far East, more than two million tons of fresh seaweed per year is processed to obtain food products, while almost 1.5 million tons per year is used in industrial production to obtain alginates, phycocolloids and carrageenan (Jiménez-Escrig and SánchezMuniz, 2000). Primary and secondary metabolites obtained from seaweeds are considered as future foods and attract attention for economic exploitation (Cardozo et al., 2007). People living in coastal areas consume seaweeds in both fresh and dried form.
In Japan, 25\% of all food contains seaweed-based ingredients or seaweeds served in various forms, thus seaweeds are a basic source of livelihood for fishermen or seaweed farmers (Norziah and Ching, 2000). Consumption of about $100 \mathrm{~g}$ of seaweed is sufficient to provide the daily requirement of vitamin $A, B_{2}$, and $\mathrm{B}_{12}$; it also provides two-thirds of the daily vitamin $\mathrm{C}$ requirement (Škrovánková, 2011).

Nutrients synthesized by the human body or precursor molecules taken in the daily diet are essential for normal growth and development, and also play a very important role in the regulation of body function (Gropper and Smith, 2012). The chemical composition of seaweed is not well known so far compared to that of terrestrial plants but it is known to be rich in metabolites which act as precursor molecules that are important for human body function (Admassu et al., 2015).

\section{Proteins}

Proteins are polymers of amino acids which are bound together by peptide bonds. The protein composition and content of marine algae vary among species and depend on season and habitat (Pangestuti and Kim, 2015). Accordingly, the nutritional value of seaweed proteins varies depending on the geographical location and environmental conditions (Kadam et al., 2017). It is well established that brown seaweeds contain the least protein while moderate concentrations of protein are reported from green seaweeds and the highest content is estimated in red seaweeds (Ganesan et al., 2019). Protein content varies a lot over time (season), with the highest concentrations present during the beginning of spring and winter, while the minimum concentration is present during the early autumn period and summer (Denis et al., 2010). Phycobiliproteins and lectins are bioactive proteins obtained from seaweeds that have been exploited for several industrial applications (Bleakley and Hayes, 2017). Lectins are low molecular weight thermostable proteins attached to definite carbohydrates and take part in many biological activities such as intercellular communication (Chojnacka et al., 2012). The nutritional value of protein depends on two factors: amino acid composition and protein digestibility (Tabarsa et al., 2012). A protein which has an exceptional amino acid composition would not have great nutritional value if its digestibility remains low (Tseng, 2001). Most seaweeds are a rich source of glycine, arginine, glutamic acid, and alanine which are essential for human health, and their concentrations make them an excellent part of the diet (Aguilera-Morales et al., 2005). Brown seaweeds are commonly exploited by industries and have a lower protein content, about 15\% of their dry weight, but Saccharina latissima (formerly Laminaria saccharina) (Ochrophyta, Phaeophyceae) is reported to have a protein content of $25.7 \%$ its dry weight (Fleurence, 1999). The higher protein content of S. latissima is a result of the favorable environmental conditions of its habitat (Fleurence, 1999). Chlorella vulgaris (Chlorophyta) is one of the seaweeds commonly exploited by industries for its high protein content, $51-58 \%$ of dry weight (Bleakley and Hayes, 2017), whereas the red algal species Neopyropia tenera (formerly Porphyra tenera) (Rhodophyta) is reported to have a protein content of up to $47 \%$ of dry weight (Sánchez-Machado et al., 2004). Some species 
of Ulva (formerly Enteromorpha) (Chlorophyta) contain key amino acids, in which 9 of 10 amino acids play a vital role for human beings and are considered equivalent to soybean proteins (Aguilera-Morales et al., 2005). Seaweed proteins have been reported to have different biological activity such as antihypertensive [angiotensin-I-converting enzyme (ACE) inhibition], antioxidant and antidiabetic effects (Admassu et al., 2018). The physiological activities of the human body are affected by bioactive peptides which are part of the food diet. In parent proteins, a short sequence of amino acids is present in an inactive form, but they break into short bioactive peptides during food processing, gastrointestinal digestion or fermentation, and research suggests that these activated bioactive peptides have nutraceutical potential to promote human health (Wijesekara and Kim, 2010).

\section{Polysaccharides}

Seaweeds are considered a source of novel and unique types of polysaccharides having diverse applications (Tanna and Mishra, 2019). Monosaccharides linked together by glycosidic bonds result in the formation of polysaccharides; they may be homopolymers or heteropolymers depending on their monosaccharide composition. Homopolysaccharides comprise repeats of a single type of monosaccharide and/or its derivative such as cellulose, an important structural component of the cell wall of plants and most seaweeds (Stiger-Pouvreau et al., 2016). Unlike homopolymers, heteropolysaccharides consist of repeats of different types of sugar molecules and/or their derivatives such as carrageenan (Rhodophyta) and ulvan (Chlorophyta) (Stiger-Pouvreau et al., 2016). Polysaccharides have several important commercial applications including as thickeners, stabilizers, beverages, feed, emulsifiers, food, etc (Tseng, 2001). Their low calorific value makes seaweeds nutritionally important (Pereira, 2011). The cell wall of seaweeds contains a huge amount of polysaccharides (Pádua et al., 2015). Storage and cell wall polysaccharides are species-specific (Kraan, 2012). The seaweed cell wall typically consists of sulfated polysaccharides that distinguish it from that of land plants (as they do not have such polysaccharides) and these polysaccharides have a useful function in ionic regulation (Rupérez et al., 2002). The characteristics of seaweed polysaccharides differ not only from those of terrestrial plants but also vary according to the taxonomy of seaweeds. Like proteins, polysaccharides have different building blocks (sugar repeats) and their functional properties depend on their structural composition (Wijesinghe et al., 2011a). The compounds present in carbohydrates vary according to age, species, season, and the geographical location of the species (Gupta and Abu-Ghannam, 2011). This fibers may be water-insoluble or water-soluble and is related to different physiological properties (Gómez-Ordóñez et al., 2010). Various soluble polysaccharides like guar gum, pectins, etc., have been correlated with hypoglycemic and hypocholesterolemic effects while water-insoluble polysaccharides like cellulose are linked to reduced digestive tract transit time (Burtin, 2003). Polysaccharides are classified into three groups: (a) storage polysaccharides, (b) intercellular mucilage, and (c) structural polysaccharides (Ito and Hori, 1989). Polysaccharides stimulate the growth of many bacteria present in the digestive tract and thus they are beneficial for digestion (Vidanarachchi et al., 2009), whereas many bacterial and virus species are inhibited by sulfated polysaccharides (Leonard et al., 2010).

The most important bioactive polysaccharides exclusively found in seaweeds are fucoidan, laminarin and alginates. Fucoidan is a sulfated polysaccharide isolated from the Phaeophyceae group comprised of sulfated L-fucose as the main sugar unit, in which sulfate ester groups are linked to fucose by $\alpha-1,3$ linkages ( $\mathrm{Li}$ et al., 2008). Fucoidan is estimated to be about $10 \%$ of seaweed dry weight (Chojnacka et al., 2012). The bioavailability and absorption of sugars commonly depend on their molecular weight, and low molecular weight fucoidans are highly bioavailable compared to high molecular weight fucoidans (Zuo et al., 2015). Furthermore, fucoidan shows antioxidant, antiviral, antitumor, antioxidative and anti-inflammatory activity (Song et al., 2012).

Another widely explored polysaccharide, laminarin, commonly obtained from brown seaweeds, is made up of $\beta(1-3)$-linked glucose in the main chain with random $\beta(1-6)$ linked side-chains (O'Doherty et al., 2010). It has antibacterial and antiviral activity, and also acts as a prebiotic. The antioxidant activity of laminarin depends on its chemical structure and molecular weight ( $\mathrm{Li}$ and Kim, 2011). Alginates are a unique type of polysaccharide exclusively present in seaweeds, especially brown seaweeds, and absent in terrestrial plants (Kumar et al., 2008). Alginates were reported to account for up to $47 \%$ of the dry weight of total biomass (Holdt and Kraan, 2011). Interestingly, alginates may be present in salt or acidic forms. The acidic form of the polymer is called alginic acid and comprises two types of hexuronic acid monomer: $\beta$-D-mannuronic acid and $\alpha$-Lguluronic acid, linked with 1-4 bonds (Andriamanantoanina and Rinaudo, 2010). They have antibacterial and anti-inflammatory activity and also have thickening, stabilizing and general colloidal properties (Aliste et al., 2000). The importance of seaweed polysaccharides in industrial and biomedical applications has been proved. They have been isolated from different classes of seaweeds: carrageenans and agarans from red seaweed; alginates and fucoidans from brown seaweed; and ulvans from green seaweed (Cosenza et al., 2017).

\section{Mineral Content}

Seaweeds contain high concentrations of a wide range of diversified minerals due to their habitat. Most of the minerals required for human health such as potassium, sodium, phosphorus, calcium, iodine, magnesium, iron, and zinc are present in sufficient quantities in seaweeds, thus they have the potential to be widely used as health-beneficial supplements (Rao et al., 2007). Trace elements have also been reported in seaweeds (Burtin, 2003). Iodine plays an important role in the performance of thyroid function (Jaspars and Folmer, 2013), and Fucus vesiculosus (Ochrophyta, Phaeophyceae) is reported to contain a high iodine concentration of up to $600 \mathrm{mg} / \mathrm{g}$ (Bove et al., 2010). Certain minerals have a linkage with anionic polysaccharides including agar, alginates or carrageen, and these linked minerals provide a linkage between anionic polysaccharides which affect their digestibility (Jiménez-Escrig et al., 2011). In contrast, 
carboxylic polysaccharides (e.g., alginic acid) have a strong affinity for divalent cations, mostly calcium that regulates the availability of associated minerals (Mabeau and Fleurence, 1993). Some seaweed species are also known for the presence of a high amount of mineral elements with particular catalytic functions, such as Ulva (formerly Enteromorpha) spp. (Chlorophyta) which have high concentrations of magnesium (2-5\% of dry matter).

A high mineral content has been reported in seaweeds, sometimes up to $40 \%$ of biomass (Kumar et al., 2011); this happens because seaweeds absorb metal ions from salt water and accumulate them in their fronds as carbonate salts (Chojnacka et al., 2012). Seaweeds contain calcium in the form of calcium phosphate which is considered more bioavailable than the calcium carbonate form commonly present in milk (Rajapakse and Kim, 2011). Iodine is considered one of the prominent requirements for health, and in some seaweeds the iodine concentration is higher than the minimum human dietary requirement (150 mg/day) (Rajapakse and Kim, 2011). The highest iodine content is found in brown seaweeds; while red and green seaweeds have a lower iodine content (Rajapakse and Kim, 2011), it is still higher than that in terrestrial plants. Therefore, seaweeds can also be considered as an alternative food to fulfill the requirement for iodine compared to animaland plant-derived foods (Rajapakse and Kim, 2011). It has also been observed that the linkage between polysaccharides and iodine is weak, which allows rapid release of the iodine. Iron and copper content is also high in seaweeds compared to plant and animal food sources, even higher than in spinach and meat (Holland et al., 1993). Overall, seaweeds may be considered the best food to be explored for fulfilling the mineral requirements of human body (Pereira, 2011). Research on Sargassum ringgoldianum (Ochrophyta, Phaeophyceae) seaweed harvested from Japanese beaches showed a balanced combination of potassium $(69 \mu \mathrm{mol} / \mathrm{ml})$, magnesium $(7.8 \mu \mathrm{mol} / \mathrm{ml})$, and calcium (4.1 $\mu \mathrm{mol} / \mathrm{ml})$ ions (Kuda and Ikemori, 2009). Similarly, Kappaphycus alvarezii (Rhodophyta) is rich source of calcium and magnesium, with about 460.11 and $581.20 \mathrm{mg} / \mathrm{L}$, respectively, present in their extracts (Rathore et al., 2009).

\section{Vitamins}

Vitamins are important nutrients for achieving specific and essential functions of the body and are also essential for maintaining health (Bellows et al., 2012). Seaweeds are rich in all essential and non-essential vitamins (Ganesan et al., 2019). Some seaweeds possess vitamins that have many healthbeneficial effects and antioxidant activity, and thus reduce various health-related problems including high blood pressure, cardiovascular disorders and the risk of cancer (Gupta et al., 2020). Water-soluble vitamins $B_{1}, B_{2}, B_{12}$, and $C$, and fat-soluble vitamins $E$ and $\beta$-carotene with vitamin $A$ activity have been reported from various seaweeds (Škrovánková, 2011). Deficiency of water-soluble vitamins such as $B_{12}$ causes many diseases like chronic fatigue syndrome (CFS), anemia and many skin problems. Vitamin $B_{12}$ is not synthesized by most terrestrial plants, but many prokaryotes capable of synthesizing vitamin $\mathrm{B}_{12}$ interact with seaweeds, and this interconnection promotes vitamin levels in macroalgae (Cotas et al., 2020). Vitamin $B_{12}$ is abundant in Arthrospira (formerly Spirulina) (Cyanobacteria) which has four times more $\mathrm{B}_{12}$ than raw liver (Falquet and Hurni, 1997); consumption of $1 \mathrm{~g}$ of Arthrospira (formerly Spirulina) is sufficient to provide the daily requirement of $\mathrm{B}_{12}$ (Watanabe et al., 1999). Brown and green seaweeds are a rich source of vitamin A, containing on average between 500 and $3000 \mathrm{mg} / \mathrm{kg}$ of dry weight, whereas red algae contain 100$800 \mathrm{mg} / \mathrm{kg}$ dry weight (Kumar et al., 2008). Various seaweeds, including Crassiphycus changii (formerly Gracilaria changii), Porphyra umbilicalis (Rhodophyta) and Himanthalia elongata (Ochrophyta, Phaeophyceae), are rich in vitamins compared to terrestrial vegetables (Ganesan et al., 2019). Seaweeds rich in vitamins (A, B, C, D, and E) are extensively used for skincare (Jesumani et al., 2019). Vitamin C reduces the harshness of allergic reactions to fight off infection, enhances the immune defense system, regulates the formation of conjunctive tissue and helps in removing free radicals, and also plays a significant role in many diseases and disorders such as diabetes, atherosclerosis, cancer and neurodegenerative problems (Chambial et al., 2013). The vitamin $\mathrm{C}$ concentration in the seaweed Eisenia arborea (Ochrophyta, Phaeophyceae) (34.4 mg/100 g DW) is similar to that in mandarin oranges $(37.7 \mathrm{mg} / 100 \mathrm{~g}$ ) (HernándezCarmona et al., 2009). The brown seaweeds Ascophyllum and Fucus sp. contain 200-600 $\mathrm{mg} / \mathrm{Kg}$ DW of vitamin E ( $\alpha$-tocopherols), more than other red and green seaweeds (Mathew and Ravishankar, 2018). The seaweed Macrocystis pyrifera (Ochrophyta, Phaeophyceae) is highly rich in vitamin $\mathrm{E}$, similar to the plant oils which are known for being rich in vitamin E such as soybean oil (Glycine max), sunflower seed oil (Helianthus annuus) and palm oil (Elaeis guineensis) (Mathew and Ravishankar, 2018). Vitamin E inhibits oxidation of lowdensity lipoprotein and also plays a vital role in the prevention of cardiovascular diseases (Solibami and Kamat, 1985). Seaweed consumption (about $100 \mathrm{~g} /$ per day) gives more than the daily requirement of vitamins $A, B_{2}$, and $B_{12}$ and fulfils two-thirds of the vitamin $C$ requirement (Ortiz et al., 2006).

\section{Pigments}

Pigments are lipid-soluble polyenes, and natural pigments not only function as factors providing color but also participate in many biological activities ( $\mathrm{Li}$ and Kim, 2011). Pigments are widely found in seaweeds, plants, invertebrates, and mammals. Marine algae are potential sources of unique natural pigments (Pangestuti and Kim, 2015). Seaweeds contain three classes of pigments: chlorophylls, phycobiliproteins and carotenoids (Pereira et al., 2014). Chlorophylls are not absorbed by the human body and are therefore transformed into pheophorbide, pyropheophytin and pheophytin in processed vegetable foods which can be easily absorbed. Chlorophylls have an antimutagenic effect and may play a significant role in cancer prevention (Ferruzzi and Blakeslee, 2007). Phycobiliproteins are water-soluble pigments produced by red seaweeds in high concentrations (Mihova et al., 1996). Phycobilins show antioxidant, antiviral, anti-inflammatory and neuroprotective properties (Holdt and Kraan, 2011). Seaweed carotenoids include xanthophylls (zeaxanthin, violaxanthin, lutein, fucoxanthin, neoxanthin, antheraxanthin, and astaxanthin) and carotenes 
( $\beta$-carotene) (Manivasagan et al., 2018). Seaweeds that are rich in pigments have potential to be used as dietary supplements. Fucoxanthin is considered a non-provitamin A carotenoid and is found in numerous classes of algae but in Phaeophyceae, fucoxanthins are the most abundant xanthophyll, accounting for $70 \%$ of total carotenoid content (Holdt and Kraan, 2011). Fucoxanthin has various health-beneficial activities such as antiobesity and cancer chemoprevention (Woo et al., 2009). Different types of carotenoid reported from various classes of marine algae show strong antioxidant activity (Galasso et al., 2017). Carotenoids have the ability to quench singlet oxygen and scavenge free radicals (Islamian and Mehrali, 2015). Seaweeds are rich in carotenoids reported to reduce cardiovascular diseases, age-related diseases, dementia, inflammation, diabetes, and cancers as well as opthalmological diseases (Tan and Norhaizan, 2019). A number of studies have confirmed the antioxidant properties of seaweed carotenoids and their role in preventing diseases that are linked to oxidative stress (Okuzumi et al., 1993). The carotenoid composition of 16 red seaweeds shows that red seaweeds have high concentrations of lutein and zeaxanthin, and in 12 species of the Rhodophyta phylum the carotenoid content shows high concentrations of antheraxanthin, violaxanthin and $\beta$-carotene (Schubert et al., 2006). Seaweed $\beta$-carotene content ranges from 0.248 to $0.357 \mathrm{mg} / \mathrm{g}$ (Abirami and Kowsalya, 2011). Chlorophyll, $\beta$-carotene and fucoxanthin have various biologically beneficial activities that include antimutagens, antioxidant and antiproliferative activity for cancer (de Quirós et al., 2010). Chlorophyll a, $\beta$-carotene and lutein extracted from the seaweed Neopyropia tenera (formerly Porphyra tenera) (Rhodophyta) exhibit anti-mutagenic activity by suppressing the expression of the mutagen-induced umuC gene (Okai et al., 1996). Seaweed carotenoids are also used for their antimicrobial activity (Rajauria and Abu-Ghannam, 2013).

\section{Polyphenols}

Polyphenols are a group of chemical compounds consisting of a hydroxyl group $(-\mathrm{OH})$ that is directly linked to an aromatic hydrocarbon group. Polyphenols are derived differently in plants and seaweeds: they are derived from gallic and ellagic acid in plants, whereas in seaweeds they derive from polymerized phloroglucinol units (1,3,5-trihydroxybenzene) (Generalić Mekinić et al., 2019). Seaweed polyphenols include flavonols, catechins and phlorotannins (Gómez-Guzmán et al., 2018). Marine algal phlorotannins are an extremely heterogenous group of molecules (in terms of structure and degree of polymerization) and thus have a wide range of potential biological activity (Li et al., 2017). Phlorotannins range from 5 to $15 \%$ of the dried weight, highest in brown seaweeds followed by red and green (Ragan and Jensen, 1978). In green and red algae, the major percentage of phenolic compounds are flavonoids, phenolic acids and bromophenols (Wells et al., 2017). Bromophenol is one of the key phenolic compounds detected in marine algae and is found at a high level in various types of seaweeds such as Leathesia marina (formerly Leathesia nana) (Ochrophyta, Phaeophyceae), and Rhodomela confervoides (Rhodophyta) (Shi et al., 2009). The antioxidant properties of seaweeds are highly affected by their polyphenol composition (Martins et al., 2013; Tanna et al.,
2019). Polyphenols convert free radicals to non-reactive radicals by donating a hydrogen molecule (Gupta and Abu-Ghannam, 2011). Polyphenol content also shows a significant temporal correlation with the reproductive state of seaweeds (Ragan and Jensen, 1978). Phlorotannins isolated from Eisenia bicyclis (Ochrophyta, Phaeophyceae) have shown antioxidant activity 10 times higher than that of ascorbic acid and $\alpha$-tocopherol (Shibata et al., 2007). Seaweeds generate polyphenols to protect themselves from herbivores and external biotic and abiotic stresses (Li and Kim, 2011). In the brown seaweed Himanthalia elongata, a total of seven polyphenols (phloroglucinol, gallic acid, chlorogenic acid, caffeic acid, ferulic acid, myricetin, and quercetin) were observed to have a higher antioxidant activity than ascorbic acid (Rajauria, 2018). Polyphenols extracted from the brown seaweed Fucus vesiculosus collected from Kiel Fjord, Western Baltic Sea, showed anticancer activity (Zenthoefer et al., 2017). Eucheuma and Kappaphycus spp. (Rhodophyta) have higher antioxidant activity than $\alpha$-tocopherol (Ganesan et al., 2008). Seaweed phenols have scavenging ability due to the presence of a hydroxyl group, which is why it is an important constituent of seaweed (Wang et al., 2009). Phlorotannin-rich extract of the seaweed Ascophyllum nodosum (Ochrophyta, Phaeophyceae) has various biological activities such as inhibition of oxidative stress, and anti-inflammatory and anti- senescence activity (Dutot et al., 2012). Dieckol, a phlorotannin extracted from the brown seaweed Ecklonia cava (Ochrophyta, Phaeophyceae), inhibits adipogenesis by activating the AMP signal pathway (Ko et al., 2013). The flavonoids in the green seaweed Ulva prolifera (formerly Enteromorpha prolifera) (Chlorophyta) have therapeutical potential as type 2 diabetes suppressors (Yan et al., 2019). Seaweed bromophenol is known as a very strong cytotoxic agent against various cancer cells: Vertebrata lanosa (formerly Polysiphonia lanosa) and Neorhodomela larix (formerly Rhodomela larix (Rhodophyta) show cytotoxic activity against DLD-1 cells and HCT-116 cells (Weinstein et al., 1975; Shoeib et al., 2004). Moreover, phenolic compounds are involved in stabilizing lipid peroxidation (Vijayabaskar and Shiyamala, 2012).

\section{Fatty Acids}

Seaweeds contain low concentrations of lipids, about $2-10 \%$ of their dry weight. It has also been noticed that tropical seaweed species have lower lipid concentrations than cold water algae (Holdt and Kraan, 2011). The most common lipids found in seaweed are phospholipids and glycolipids. Most seaweed lipids are comprised of polyunsaturated fatty acids (PUFAs); further, their concentration is high in those seaweeds which grow in cold regions compared to temperate climate zones (Balić et al., 2020). Commonly, PUFAs are classified in two forms, omega-3 and omega- 6 fatty acids. Both lipids consist of at least 20 carbon atoms with at least two double bonds; when the third carbon atom has the first double bond, it is referred to as omega-3, whereas if the first double bond is present at the sixth carbon position, it is known as omega-6. Long chain PUFAs (LC-PUFAs) play a crucial role in cellular and tissue metabolism, including the regulation of membrane fluidity, electron and thermal adaptation, and oxygen transport (van Dooremalen et al., 2009). Both omega-3 and 
omega- 6 fatty acids are essential for balanced human metabolic procedures, and thus are important ingredients in the human diet. The quantity of omega- 3 and omega- 6 fatty acids consumed should be balanced because both use the same metabolic enzymes to produce prostaglandins (Simopoulos, 2016). A hugely imbalanced $\omega-6 / \omega-3$ ratio is the reason behind various health issues such as cancer and inflammatory, cardiovascular and autoimmune diseases (Simopoulos, 2008). According to the WHO, the $\omega-6 / \omega-3$ ratio must be lower than 10 (Francavilla et al., 2013). Seaweeds have many crucial fatty acids, which may add to their efficacy as a dietary supplement or as part of a balanced diet (Admassu et al., 2015). The brown seaweed Cystoseira humilis (Ochrophyta, Phaeophyceae) has a high fatty acid content, about $48 \%$ compared to other brown seaweeds studied from the Atlantic coast of Morocco, in which PUFAs, linoleic acid (C18:2) and arachidonic acid (C20:4) are abundant (Belattmania et al., 2018). Fatty acids of Cystoseira humilis (Ochrophyta, Phaeophyceae) show antioxidant and antibacterial activity (Belattmania et al., 2016). The fatty acid composition of seaweeds varies with the season; for example, in the marine alga Spatoglossum macrodontum (Ochrophyta, Phaeophyceae), the highest total fatty acid content (about $83 \mathrm{mg} / \mathrm{g} \mathrm{DW}$ ) is found in the month of July (start of growth), which declined $30 \%$ in August (initial growth phase) and the lowest (55-66 mg/g DW) in November (biomass peak stage or end of growth). Their PUFA composition also changes with the season, being initially high (39\%) at the start of growth; reducing concomitantly with later stages of growth and reaching up to $31 \%$ at the end of the growth period (Gosch et al., 2015). In the seaweed Gracilaria gracilis (Rhodophyta), the amount of fatty acids also changes with the season; for example the $\omega-6 / \omega-3$ ratio is lowest in April while it increases more than 10 times in January (Francavilla et al., 2013).

\section{BIOLOGICAL ACTIVITY}

\section{Antihypertensive Activity}

It is well established that hypertension or high blood pressure and oxidative stress are major reasons for the development of various chronic diseases. In hypertension, blood pressure increases concomitantly and results in stroke or many other cardiovascular diseases like coronary infarction. Macroalgal peptides are well-known natural compounds for the inhibition of ACE activity; even peptides from sources other than macroalgae have antihypertensive activity (Li et al., 2016; Lee and Hur, 2017). The blood pressure-lowering peptide bradykinin is degraded by the multifunctional ACE attributing high blood pressure, which plays a key role in cardiovascular diseases (Martin and Deussen, 2019). Inhibition of ACE is considered a useful therapeutic approach and dipeptides isolated from the seaweed Undaria pinnatifida (Ochrophyta, Phaeophyceae) showed effective inhibition of ACE (Kim and Wijesekara, 2010). Seven different peptides, Val-Tyr, Ile-Tyr, Ala-Trp, Phe-Tyr, ValTrp, Ile-Trp, and Leu-Trp, showed antihypertensive activity, with $\mathrm{IC}_{50}$ of $35.2,6.1,18.8,42.3,3.3,1.5$, and $23.6 \mu \mathrm{M}$, respectively (Sato et al., 2002). Each peptide showed an antihypertensive effect in spontaneously hypertensive rats (SHR); briefly, at a dose of $1 \mathrm{mg} / \mathrm{kg}$ of body weight, the blood pressure was considerably reduced by Ile-Trp, Ile-Tyr, Val-Tyr, and Phe-Tyr (Sato et al., 2002). The renin-angiotensin-aldosterone system (RAAS) is a hormone system that regulates blood pressure; is also of interest to researchers in combating hypertension. The enzyme papain isolated from the red seaweed Palmaria palmata (Rhodophyta) generates a renin-inhibitory tridecapeptide with a motif of IRLIIVLMPILMA (Fitzgerald et al., 2014). This tridecapeptide and some other seaweed-protein hydrolyzates (yet to be characterized) have shown an antihypertensive effect by decreasing systolic blood pressure (SBP) in the SHR model (Fitzgerald et al., 2014). It was found that protein hydrolyzate (tridecapeptide IRLIIVLMPILMA) from the seaweed Palmaria palmata reduces SBP by about $34 \mathrm{~mm} \mathrm{Hg}$, from about 188 to $154 \mathrm{~mm} \mathrm{Hg}$ (Fitzgerald et al., 2014). Five different enzymatic digests extracted from the brown seaweed Ecklonia cava have potential ACE I inhibitory activity, with $\mathrm{IC}_{50}$ values ranging from 2.33 to $3.56 \mu \mathrm{g} / \mathrm{ml}$ (Cha et al., 2006). Phlorotannins (phlorofucofuroeckol A, dieckol, and eckol) isolated from Ecklonia stolonifera show the inhibitory activity ( $\mathrm{IC}_{50}$ values $12.74 \pm 0.15,34.25 \pm 3.56$, and $70.82 \pm 0.25 \mu \mathrm{M}$, respectively) against ACE (Jung et al., 2006). Among five phlorotannins from the seaweed E. cava, triphlorethol A, eckstolonol, dieckol, eckol and phloroglucinol, dieckol exhibited the strongest inhibitory activity against ACE. Dieckol significantly increased the production of NO in EAhy926 cells and does not have any cytotoxic effect (Wijesinghe et al., 2011b; Ko et al., 2017). Fucoxanthin obtained from Saccharina japonica and Sargassum horneri (Ochrophyta, Phaeophyceae) shows antihypertensive activity (Sivagnanam et al., 2015).

\section{Antiproliferative Activity}

Cancer is the reason for the increase in mortality rate worldwide, and peptides have effective therapeutic applications. Cancer is the result of irregular growth or development of cells, which leads to the alteration of cell physiology including self-determination of growth signals, insensitivity of growth inhibitory signals, avoidance of programmed cell death (apoptosis), uncontrolled replicative repetition, constant angiogenesis, tissue invasion and metastasis. An anticancer undecapeptide with the amino acid sequence VECYGPNRPQF, isolated from the green microalga Chlorella vulgaris waste by pepsin hydrolysis, showed antiproliferation in a dose-dependent manner in AGS cells, with an $\mathrm{IC}_{50}$ value of $70 \mu \mathrm{g} / \mathrm{ml}$, and also induced post-G1 cell cycle arrest (Sheih et al., 2010). This peptide also showed high antioxidant activity compared to trolox in the case of peroxyl radicals and low-density lipoproteins (Sheih et al., 2009). A number of polysaccharides extracted from different seaweeds were evaluated for their antiproliferative activity on different cell lines. An effective treatment for cancer is still a major research focus, and the quest to find alternative therapies and natural drugs is ongoing. In cancer, uncontrolled cell division occurs, which spreads into nearby tissues and forms tumors. Many factors are responsible for causing cancer, including an unhealthy diet, the use of drugs, environmental toxins, infectious organisms, hormones and inherited genetic mutations. Sulfated polysaccharides obtained 
from the green seaweed Caulerpa prolifera inhibited cell proliferation by about $57 \%$ with a $0.1 \mathrm{mg} / \mathrm{ml}$ dose (Costa et al., 2010). Sulfated polysaccharides extracted from Sargassum filipendula (Ochrophyta, Phaeophyceae) showed about 60\% cell proliferation inhibition at a dose of $0.1 \mathrm{mg} / \mathrm{ml}$ (Costa et al., 2011). S. oligocystum (Ochrophyta, Phaeophyceae) showed antiproliferative activity at an $\mathrm{IC}_{50}$ of $2.52 \pm 0.54 \mu \mathrm{g} / \mathrm{ml}$ against an adriamycin-resistant human small cell lung carcinoma (GLC4/Adr) cell line (Praiboon et al., 2018). Polysaccharide fraction SF-0.7v exhibited the most effective antiproliferation activity on HepG2 and PC3 cells, whereas fractions SF-1.0v and SF-1.5v showed strong inhibition of HeLa cells, with $\mathrm{IC}_{50}$ values of 15.69 and $13.83 \mu \mathrm{M}$, respectively (Costa et al., 2011). Polysaccharides obtained from Ecklonia cava had an $\mathrm{IC}_{50}$ of $44 \mu \mathrm{g} / \mathrm{ml}$ in the U-937 cell line (Athukorala et al., 2009). Results determined by nuclear staining with Hoechst- 33342 showed that the polysaccharides induce apoptosis (Athukorala et al., 2009). A polyphenol-rich extract of Kappaphycus alvarezii (formerly Eucheuma cottonii) (Rhodophyta), an edible red seaweed, showed antiproliferative activity in the oestrogen-independent human breast cancer cell line MB-MDA-231 with an $\mathrm{IC}_{50}$ value of $42 \mu \mathrm{g} / \mathrm{ml}$ and in the oestrogen-dependent MCF-7 with an $\mathrm{IC}_{50}$ value of $20 \mu \mathrm{g} / \mathrm{ml}$ (Namvar et al., 2012). Polyphenols have no harmful effect on normal cell lines and a seaweed extract shows dose-dependent anti-oestrogenic effects on the rat oestrous cycle and serum hormone concentration (Namvar et al., 2012). It induces apoptosis without cell cycle arrest to maintain cellular homeostasis; biosynthesis of endogenous oestrogen is downregulated in the rats to suppress the tumor. It also improves antioxidant activity by improving oxidative status (Namvar et al., 2012). The brown seaweed Sargassum muticum has antiproliferative activity against MDA-MB-231 and MCF-7 breast cancer cell lines (Namvar et al., 2013). Fucus vesiculosus, a brown seaweed harvested from the Baltic Sea, had cytotoxic activity against two human pancreatic cancer cell lines, Panc89 and PancTU1 (Zenthoefer et al., 2017). Species of the tropical green seaweed Caulerpa from Arabian Sea show potential anticancer activity by regulating differential expression of key cancer-linked genes (Tanna et al., 2020).

\section{Anticoagulant Activity}

Bleeding is a very common and serious problem in the case of low anticoagulant activity (Landefeld and Beyth, 1993). Seaweed polysaccharides show anticoagulant activity by affecting antithrombin III (AT III) and promoting heparin cofactor II (HC II), as significant endogenous inhibitor, while some others directly suppress fibrin polymerization and thrombin activity without interacting with AT III and HC II (Shoeib et al., 2004). The sulfated polysaccharide ulvan obtained from the green seaweed Ulva rigida has strong biological activity as an anticoagulant compared to Lovenox in the case of both intrinsic and extrinsic coagulation pathways (Adrien et al., 2019). The anticoagulant activity of seaweeds depends on the molecular weight of fucoidans and also on their galactose content. Seven fucoidans extracted from the seaweed Saccharina japonica (Ochrophyta, Phaeophyceae) vary in average molecular weight and four of them vary in both average molecular weight and fucose to galactose molar ratio. The activated partial thromboplastin time (APTT) assay results for these fucoidans explain that higher molecular weight fucoidans have high anticoagulant activity which further increases the galactose content (Jin et al., 2013). An extract of the sulfated polysaccharide-rich green seaweed Udotea flabellum $(3 \mu \mathrm{g})$ showed double the plasma coagulation time in the APTT assay, similar to the results obtained with $1 \mu \mathrm{g}$ heparin (Mendes Marques et al., 2019). Different fucans obtained from the brown algae Padina gymnospora exhibit potential anticoagulant activity (Silva et al., 2005); similarly, sulfated polysaccharides from the brown seaweed Sargassum fulvellum also showed strong anticoagulant activity in the APTT assay (De Zoysa et al., 2008). Six families of sulfated polysaccharides extracted from the marine algae Dictyopteris delicatula (Ochrophyta, Phaeophyceae) showed anticoagulant activity by the APPT test, proving that these polysaccharides suppress both the intrinsic and common pathways of coagulation and that some polysaccharide fractions have anticoagulant activity similar to that of Clexane (a commercial anticoagulant drug) (Magalhaes et al., 2011). Ion exchange-purified polysaccharides from three seaweeds, Laurencia filiformis (formerly Gracilaria filiformis) (Rhodophyta), Ulva compressa (formerly Enteromorpha compressa) (Chlorophyta) and Turbinaria conoides (Ochrophyta, Phaeophyceae), prolonged the coagulation of human plasma tested by the APTT assay $(39.0 \pm 1.0,38.6 \pm 1.0$ and $38.5 \pm 1.9$, respectively) (Venkatesan et al., 2019).

\section{Immunomodulatory Activity}

Macrophages are considered the most important component in the host defense mechanism against bacterial infection, and various types of invading cells including cancer cells (Hirayama et al., 2018). Activated macrophages secrete key cell factors such as cytokines, chemokines and enzymes for removal of pathogens or inhibition of cancerous cell growth (Gautam et al., 2013). The polysaccharide ulvan extracted from the seaweed Codium fragile (Chlorophyta) is suggested as a strong immunomodulator as it enhances the secretion of various cytokines and nitric acid (NO) through activated macrophages in RAW 264.7 murine macrophage cells (Lee et al., 2010). Furthermore, ulvan from Codium fragile (Chlorophyta) possesses effective immunostimulatory activity and prevents harmful inflammatory effects by enhancing the production of pro-inflammatory (interleukins; IL-1, IL-6, IL-12, and tumor necrosis factors; TNF) and anti-inflammatory cytokines (Lee et al., 2010). The polysaccharide CrvpPS, isolated from the green alga Caulerpa chemnitzia (formerly Caulerpa racemosa var. peltata), fused with nano-selenium (CrvpPSnano-Se) shows immunomodulatory activity in mice (Shen et al., 2008). The levels of peripheral T lymphocyte subgroups and natural killer cells were significantly increased in mouse spleen during treatment with CrvpPSnanoSe (Shen et al., 2008). The enzymatic extract of the brown seaweed Ecklonia cava enhances the production of splenocytes and amplifies the quantity of their monocytes, lymphocytes and granulocytes in ICR mice. It also enhances the number of $\mathrm{CD}^{+} \mathrm{T}$ cells, $\mathrm{CD} 8^{+} \mathrm{T}$ cells, and $\mathrm{CD} 45 \mathrm{R} / \mathrm{B} 220^{+} \mathrm{B}$ cells in 
treated mice as compared to untreated controls (Ahn et al., 2008). Water-soluble sulfated polysaccharides isolated from the red seaweed Nemalion elminthoides exhibit in vitro and in vivo immunomodulatory activity by proliferating macrophages and enhance the synthesis of NO and cytokines (IL- 6 and TNF) in the murine cell line RAW 264.7 (Pérez-Recalde et al., 2014). Similarly, fucoidans from Fucus vesiculosus (Ochrophyta, Phaeophyceae) have been demonstrated to have in vitro immunomodulatory activity by upregulating TNF- $\alpha$-induced secretion of matrix metalloproteinase-9 (MMP-9), an enzyme required for the migration of immune cells, in the monocytic cell line U937 (Jintang et al., 2010). Sulfated polysaccharides from the seaweed Fucus evanescens (Ochrophyta, Phaeophyceae) interact with TLR 2 and TLR 4 to trigger NF- $\mathrm{KB}$ in the eukaryotic cell line HEK293, confirming their immunomodulatory activity (Makarenkova et al., 2012). The edible seaweed Gelidium spinosum (formerly Gelidium latifolium) (Rhodophyta) that is commonly found in Indonesian coastal regions enhances the phagocytic activity of macrophages and the leukocyte content of neutrophils in BALB/C mice at an efficient dose of $100 \mathrm{mg} / \mathrm{kg}$ bw (Prasedya et al., 2019).

\section{Antiviral Activity}

Current medical and research data signify that humans are prone to various viral diseases which cause serious injury to the health. Various naturally isolated products exhibit antiviral activity similar to or even better than that of synthetics (Parvez et al., 2019). There is always a quest to develop high efficient natural antiviral drugs that can be used alone or with already discovered antivirals (Wang et al., 2012). However, several questions are unresolved such as the toxicity of drugs, their high cost due to limited availability especially in developing countries, drug efficacy and the high rate of drug resistance (Ventola, 2015). Seaweed polysaccharides are reported to have antiviral properties against a wide range of viruses including the herpes simplex virus (HSV), human immunodeficiency virus (HIV), human cytomegalovirus (HCMV), papilloma virus, vesicular stomatitis virus, and influenza A virus (Jiao et al., 2012). Polysaccharides extracted from six different seaweeds, three red seaweeds [Furcellaria lumbricalis, Vertebrata lanosa (formerly Polysiphonia lanosa) and Palmaria palmata)], two brown (Ascophyllum nodosum and Fucus vesiculosus), and one green (Ulva lactuca), have been demonstrated to have antiinfluenza viral activity. Results showed that polysaccharides from brown seaweeds have higher anti-H1N1 activity compared to green and red algae. Overall, polysaccharides extracted from F. vesiculosus showed the highest inhibitory effect on influenza A/PR/8/34 virus (Jiao et al., 2012). Similarly, polysaccharides extracted from Polycladia indica (formerly Cystoseira indica) (Ochrophyta, Phaeophyceae) showed antiviral activity against HSV, HSV-1 strain F, and HSV-2 strain MS in Vero cells (Mandal et al., 2007). The cytotoxic effect on human diploid foreskin fibroblasts of polysaccharides obtained from $P$. indica was checked and the results confirmed that they do not have any adverse effect on cell viability at concentrations of up to $1000 \mu \mathrm{g} / \mathrm{ml}$ (Mandal et al., 2007). Various seaweed species contain significant amounts of complex structural sulfated polysaccharides that exhibit capacity to suppress the duplication of enveloped viruses. Recently, the probability of low-level COVID-19 infection in Japan, China and South Korea has been linked with the traditional utilization of seaweeds (Pereira and Critchley, 2020; Tamama, 2020; Ding et al., 2021). Seaweed-based compounds such as lectin griffithsin, phycocolloid carrageenan, and ulvans are considered potential antiviral therapeutic agents against SARS-CoV-2 (Pereira and Critchley, 2020). Sulfated polysaccharides effectively inhibit SARS-CoV-2 (Kwon et al., 2020). Brown seaweed fucoidan has been tested for antiviral activity against SARS-CoV-2 infection and results show an inhibitory effect at a dose of $15.6 \mu \mathrm{g} / \mathrm{ml}$ (Song et al., 2020). Cocktail-like targeting polysaccharides extracted from the brown seaweed Ecklonia cava subsp. kurome (formerly Ecklonia kurome) show anti-SARS-CoV-2 activity by blocking essential enzymes required for the replication of coronavirus (Ding et al., 2021). Polysaccharides extracted from the green seaweed Monostroma nitidum exhibit the potential inhibition of Enterovirus 71 (EV71) infection by binding viral particles and regulating the host phosphoinositide 3-kinase/protein kinase B signaling pathway, restricting the early steps of the virus life cycle (Wang S. et al., 2020). Two fractions of a cyclic diterpene-rich extract from the brown seaweed Dictyota menstrualis have capacity to inhibit replication of Zika virus (ZIKV) by approximately $74 \%$, with an $\mathrm{EC}_{50}$ dose of 1-3 $\mu \mathrm{g} / \mathrm{ml}$ (Cirne-Santos et al., 2019).

\section{Antidiabetic Activity}

Diabetes mellitus is the result of insufficient or defective synthesis of insulin by the pancreas. It is a chronic disease; lack of insulin increases the glucose concentration in the blood which harms many systems of the body, mostly the nerves and blood vessels. Diabetes is a global public health problem, and data predictions for 2030 indicate the greatest increase in the number of people affected will be in India, the United States and China (Fröde and Medeiros, 2008). The most important source of glucose in the blood is the hydrolysis of dietary starch; two key enzymes, $\alpha$-amylase and $\alpha$-glucosidase, are involved in the breakdown of starch and intestinal absorption, respectively. A mixed carbohydrate diet increases the blood glucose concentration that can be controlled by inhibition of these two enzymes (Lordan et al., 2013). The seaweed Ascophyllum nodosum from Atlantic Canada shows antidiabetic activity; its polyphenols have been demonstrated to inhibit $\alpha$-glucosidase and glucose uptake into 3T3-L1 adipocytes by stimulatory activity in mice (Zhang et al., 2007). Mice treated with A. nodosum polyphenolic extract have reduced total concentrations of cholesterol and glycated serum protein in blood compared with untreated diabetic mice (Zhang et al., 2007). The brown seaweed Ecklonia cava subsp. stolonifera (formerly Ecklonia stolonifera) has been demonstrated to be a strong $\alpha$-glucosidase inhibitor and to have antihyperglycemic effects in non-insulin-dependent diabetic male KK-Ay mice (Iwai, 2008). Injection of polyphenols extracted from E. cava subsp. stolonifera into unfasted KK-Ay mice reduces plasma glucose and lipid peroxidation levels which suppresses hyperglycemia that occurs with aging (Iwai, 2008). Polyphenols extracted from $A$. nodosum by two different methods, cold water and ethanol extraction, have a strong $\alpha$-amylase inhibitory 
TABLE 1 | Potential seaweeds and their metabolites exhibiting potential bioactivities.

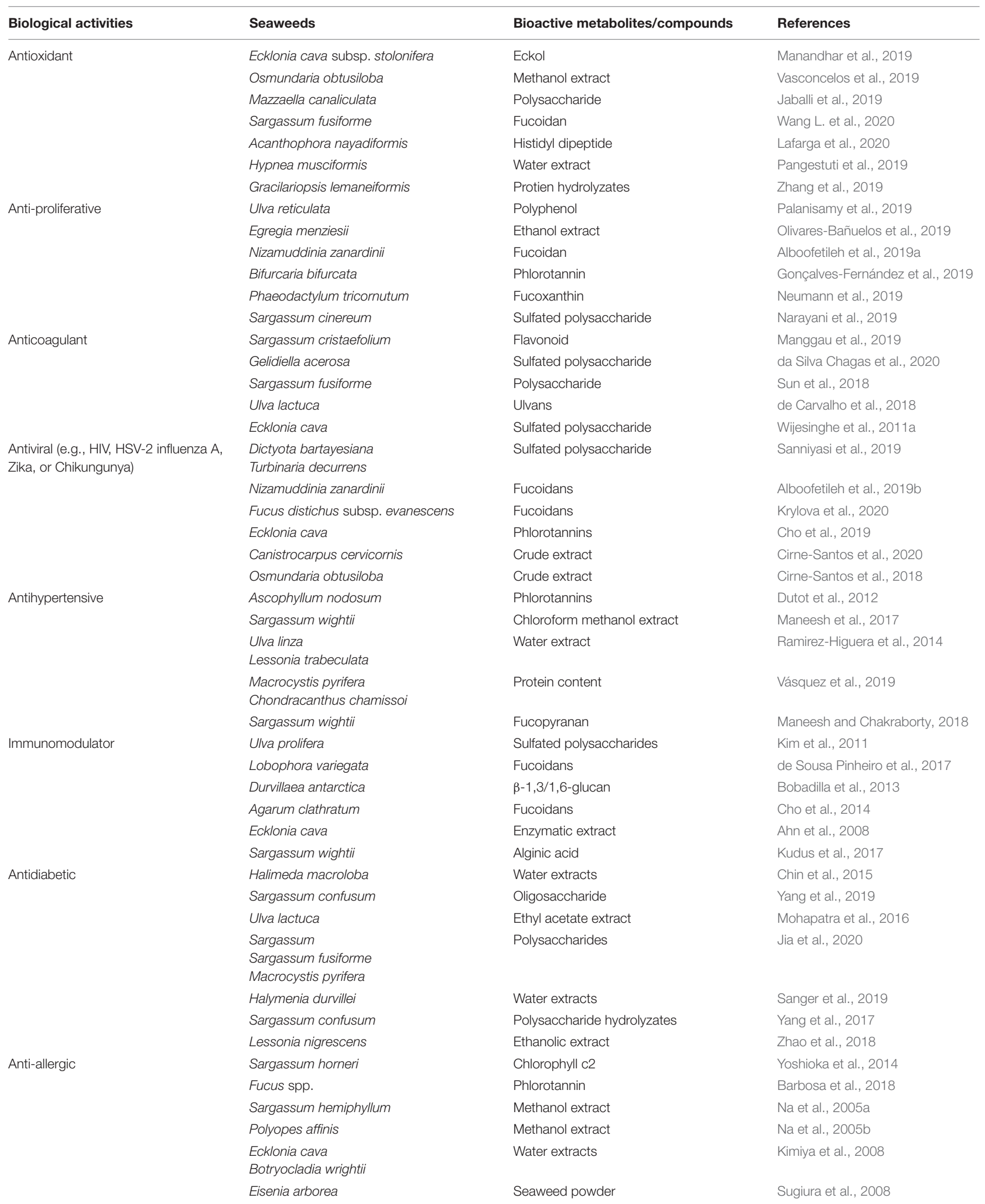


effect at concentrations of 53.6 and $44.7 \mu \mathrm{g} / \mathrm{ml}$, respectively (Iwai, 2008). Similarly, polyphenolic extracts from the seaweeds Fucus vesiculosus and its polyphenols inhibit the action of $\alpha$-glucosidase at $\mathrm{IC}_{50}$ of 0.32 and $0.49 \mu \mathrm{g} / \mathrm{ml}$, respectively (Lordan et al., 2013).

\section{Anti-allergic Activity}

On the basis of immunological responses, allergic or hypersensitive reactions can be characterized into different classes: Type I or Anaphylactic Response, Type II or CytotoxicMediated Response, and Type III or Immunocomplex Reactions (Vaillant et al., 2020). Hypersensitivity results in various clinical syndromes that include asthma, erythrism, shock, anaphylaxis and a number of other ailments. Five algae, Porphyra sp. (Rhodophyta), Saccharina japonica (formerly Laminaria japonica; Ochrophyta, Phaeophyceae), the microalga Chlorella pyrenoidosa (Chlorophyta), Scytosiphon sp. (Ochrophyta, Phaeophyceae), and Arthrospira platensis (formerly Spirulina platensis) (Cyanobacteria), were studied for their anti-allergic activity using a hyaluronidase inhibition assay (Chen et al., 2015). Scytosiphon sp. had the highest total polyphenol content and the lowest $\mathrm{IC}_{50}(0.67 \mathrm{mg} / \mathrm{ml})$ compared to the other four seaweeds. The anti-allergenic activity of polyphenolic extract of Scytosiphon sp. was compared with that of the common anti-allergic drug disodium cromoglycate (DSCG), and the results showed that Scytosiphon sp. has higher activity than the drug, with an $\mathrm{IC}_{50}$ of $1.13 \mathrm{mg} / \mathrm{ml}$. The study also showed that the anti-allergic activity is directly proportional to the concentration of polyphenol in seaweeds (Chen et al., 2015). Similarly, five brown seaweeds, Sargassum cervicorne and S. tenerrimum from Pakistan, S. graminifolium, S. thunbergii and Saccharina japonica from China were compared with DSCG and catechin, a natural tea polyphenol. The results suggested that $S$. tenerrimum is the most powerful inhibitor of hyaluronidase, with an $\mathrm{IC}_{50}$ of $21 \mu \mathrm{g} / \mathrm{ml}$, lower than that of DSCG and similar to that of catechin (Samee et al., 2009). Further, two brown seaweeds, Eisenia bicyclis and Ecklonia cava subsp. kurome, had a very effective inhibitory effect on hyaluronidase, higher than that of catechins and DSCG (Shibata et al., 2002).

\section{Insomnia}

Sound sleep is very important for human health. Sleep deficiency leads to many problems in the immune system, cognitive function and quality of life. Currently, insomnia is a major sleep disorder worldwide and around $10-15 \%$ of the population suffers from chronic insomnia, whereas another 25-35\% has temporary or infrequent insomnia. The most significant molecular targets for the discovery of sleep-enhancing drugs are $\mathrm{GABA}_{A}$ receptors (Johnston, 2015). Phlorotannins (dieckol, eckol, triphloretholA, and eckstolonol) from the seaweed Ecklonia cava induce sleep in mice by positive modulation of the GABA type Abenzodiazepine $\left(\mathrm{GABA}_{A}-\mathrm{BZD}\right)$ receptor (Cho et al., 2012). The $\mathrm{GABA}_{A}-\mathrm{BZD}$ receptor is a well-known molecule for sedatives and hypnotics, and phlorotannins obtained from $E$. cava activate the GABAA-BZD receptor to induce sleep (Cho et al., 2012). Triphlorethol A, one of the most important components of phlorotannins, shows a dose-dependent decrease of sleep latency in $\mathrm{C} 57 \mathrm{BL} / 6 \mathrm{~N}$ mice. Results show that triphlorethol A obtained from seaweed is comparable to zolpidem, a well-known hypnotic drug (Yoon and Cho, 2018).

\section{CONCLUSION AND PROSPECTS}

Seaweeds grow in large quantities in the sea and are available throughout the year. This review focuses on the bioactivity of seaweeds which are commonly consumed by humans as condiments and vegetables. Seaweed ingredients have many biological properties such as anticancer, antitumor and antiviral activity (Table 1); they also possess interesting and novel properties, particularly flavor and nutritional characteristics. From a nutritional viewpoint, their high magnesium and iron content is of human interest due to their functional or metabolic properties. Seaweeds are also rich in vitamins and specific components including fucosterol, fucoxanthin, and/or phlorotannins. Seaweed polysaccharides, which are not degraded by human enzymes, are a potential source of new types of dietary fibers. Seaweeds contain a high percentage of soluble fibers in comparison with other sources of fibers. Existing data suggest that seaweeds have a distinctive amino acid composition, in contrast to that of most terrestrial vegetables. Further research is required to analyze their nutritional value, especially biochemical analysis using modern technologies and evaluation of their bioavailability. Recent research on new seaweed-derived compounds, a different source of natural products, shows a potential area of nutraceutical study. Future research on chemical compounds derived from seaweeds should aim to study the effects of purified compounds under various conditions to recognize their true potential. Study of the physiological properties and chemical composition of seaweeds proves their aptness to be a good food fiber source for humans. Yet, further research is required to enhance our understanding of the nutritional value of these seaweeds. More research is required to evaluate their nutritional value as seaweeds are still an untapped source of health-beneficial molecules for the food processing and nutraceutical industries. Furthermore, seaweeds are an underutilized resource which can be explored by the food industries as condiments, additives or supplement ingredients for developing different types of flavor in processed foods.

\section{AUTHOR CONTRIBUTIONS}

BC collected the literature and wrote the manuscript. OC did literature survey. AM conceived the idea and designed the manuscript. All authors approved the manuscript for publication.

\section{FUNDING}

The authors gratefully acknowledges the financial support provided by the Defence Research and Development Organisation (DRDO), New Delhi. BC is thankful to UGC for JRF and subsequent SRF. CSIR-CSMCRI Communication No. PRIS-158/2020. 


\section{REFERENCES}

Abirami, R. G., and Kowsalya, S. (2011). Nutrient and nutraceutical potentials of seaweed biomass Ulva lactuca and Kappaphycus alvarezii. J. Agric. Sci. Technol. 5, 1939-1250.

Admassu, H., Gasmalla, M. A. A., Yang, R., and Zhao, W. (2018). Bioactive peptides derived from seaweed protein and their health benefits: antihypertensive, antioxidant, and antidiabetic properties. J. Food Sci. 83, 6-16. doi: 10.1111/ 1750-3841.14011

Admassu, H., Zhao, W., Yang, R., Gasmalla, M. A., and Alsir, E. (2015). Development Of Functional Foods: sea Weeds (Algae) Untouched Potential and Alternative Resource-A Review. Int. J. Sci. Technol. Res. 4, 108-115.

Adrien, A., Bonnet, A., Dufour, D., Baudouin, S., Maugard, T., and Bridiau, N. (2019). Anticoagulant activity of sulphated ulvan isolated from the green macroalga Ulva rigida. Mar. Drugs 17:291. doi: 10.3390/md17050291

Aguilera-Morales, M., Casas-Valdez, M., Carrillo-Dominguez, S., GonzálezAcosta, B., and Pérez-Gil, F. (2005). Chemical composition and microbiological assays of marine algae Enteromorpha spp. as a potential food source. J. Food Compost. Anal. 18, 79-88. doi: 10.1016/j.jfca.2003.12.012

Ahn, G., Hwang, I., Park, E., Kim, J., Jeon, Y. J., Lee, J., et al. (2008). Immunomodulatory effects of an enzymatic extract from Ecklonia cava on murine splenocytes. Mar. Biotechnol. 10, 278-289. doi: 10.1007/s10126-0079062-9

Ahn, G. N., Kim, K. N., Cha, S. H., Song, C. B., Lee, J., Heo, M. S., et al. (2007). Antioxidant activities of phlorotannins purified from Ecklonia cava on free radical scavenging using ESR and $\mathrm{H} 2 \mathrm{O} 2$-mediated DNA damage. Eur. Food Res. Technol. 226, 71-79. doi: 10.1007/s00217-006-0510-y

Alboofetileh, M., Rezaei, M., and Tabarsa, M. (2019a). Enzyme-assisted extraction of Nizamuddinia zanardinii for the recovery of sulfated polysaccharides with anticancer and immune-enhancing activities. J. Appl. Phycol. 31, 1391-1402. doi: 10.1007/s10811-018-1651-7

Alboofetileh, M., Rezaei, M., Tabarsa, M., Rittà, M., Donalisio, M., Mariatti, F., et al. (2019b). Effect of different non-conventional extraction methods on the antibacterial and antiviral activity of fucoidans extracted from Nizamuddinia zanardinii. Int. J. Biol. Macromol. 124, 131-137. doi: 10.1016/j.ijbiomac.2018. 11.201

Aliste, A. J., Vieira, F. F., and Del Mastro, N. L. (2000). Radiation effects on agar, alginates and carrageenan to be used as food additives. Radiat. Phys. Chem. 57, 305-308. doi: 10.1016/S0969-806X(99)00471-5

Amorim, K., Lage-Yusty, M. A., and López-Hernández, J. (2012). Changes in bioactive compounds content and antioxidant activity of seaweed after cooking processing. CYTA J. Food 10, 321-324. doi: 10.1080/19476337.2012.658871

Andarwulan, N., Batari, R., Sandrasari, D. A., Bolling, B., and Wijaya, H. (2010). Flavonoid content and antioxidant activity of vegetables from Indonesia. Food Chem. 121, 1231-1235. doi: 10.1016/j.foodchem.2010.01.033

Andriamanantoanina, H., and Rinaudo, M. (2010). Characterization of the alginates from five madagascan brown algae. Carbohydr. Polym. 82, 555-560. doi: 10.1016/j.carbpol.2010.05.002

Athukorala, Y., Ahn, G. N., Jee, Y. H., Kim, G. Y., Kim, S. H., Ha, J. H., et al. (2009). Antiproliferative activity of sulfated polysaccharide isolated from an enzymatic digest of Ecklonia cava on the U-937 cell line. J. Appl. Phycol. 21, 307-314. doi: 10.1007/s10811-008-9368-7

Balić, A., Vlašić, D., Žužul, K., Marinović, B., and BukvićMokos, Z. (2020). Omega-3 Versus Omega-6 Polyunsaturated Fatty Acids in the Prevention and Treatment of Inflammatory Skin Diseases. Int. J. Mol. Sci. 21:741. doi: 10.3390/ ijms 21030741

Barbosa, M., Lopes, G., Valentão, P., Ferreres, F., Gil-Izquierdo, Á, Pereira, D. M., et al. (2018). Edible seaweeds' phlorotannins in allergy: a natural multi-target approach. Food Chem. 265, 233-241. doi: 10.1016/j.foodchem.2018.05.074

Belattmania, Z., Engelen, A. H., Pereira, H., Serrão, E. A., Barakate, M., Elatouani, S., et al. (2016). Potential uses of the brown seaweed Cystoseira humilis biomass: 2-Fatty acid composition, antioxidant and antibacterial activities. J. Mater. Environ. Sci. 7, 2074-2081.

Belattmania, Z., Engelen, A. H., Pereira, H., Serrão, E. A., Custódio, L., Varela, J. C., et al. (2018). Fatty acid composition and nutraceutical perspectives of brown seaweeds from the Atlantic coast of Morocco. Int. Food Res. J. 25, 1520-1527.

Bellows, L., Moore, R., Anderson, J., and Young, L. (2012). Water-soluble vitamins: B-complex and vitamin C. Food and Nutrition Series. Health; no. 9.312. Colorado: CSU Extension.
Bleakley, S., and Hayes, M. (2017). Algal proteins: extraction, application, and challenges concerning production. Foods 6:33. doi: 10.3390/foods6050033

Bobadilla, F., Rodriguez-Tirado, C., Imarai, M., Galotto, M. J., and Andersson, R. (2013). Soluble $\beta$-1, 3/1, 6-glucan in seaweed from the southern hemisphere and its immunomodulatory effect. Carbohydr. Polym. 92, 241-248. doi: 10.1016/j. carbpol.2012.09.071

Bove, M., Stansbury, J. E., and Romm, A. (2010). Endocrine Disorders and Adrenal Support. Romm, A., Botanical Medicine for Women's Health. London: Churchill Livingstone, 193-197.

Burtin, P. (2003). Nutritional value of seaweeds. Elec. J. Environ. Agricult. Food Chem. 2, 498-503. doi: 10.1301/nr.2007.dec.535-543

Cai, Y., Luo, Q., Sun, M., and Corke, H. (2004). Antioxidant activity and phenolic compounds of 112 traditional Chinese medicinal plants associated with anticancer. Life Sci. 74, 2157-2184. doi: 10.1016/j.lfs.2003.09.047

Cardozo, K. H., Guaratini, T., Barros, M. P., Falcão, V. R., Tonon, A. P., Lopes, N. P., et al. (2007). Metabolites from algae with economical impact. Comp. Biochem. Physiol. C Toxicol. Pharmacol. 146, 60-78. doi: 10.1016/j.cbpc.2006. 05.007

Cha, S. H., Ahn, G. N., Heo, S. J., Kim, K. N., Lee, K. W., Song, C. B., et al. (2006). Screening of extracts from marine green and brown algae in Jeju for potential marine angiotensin-I converting enzyme (ACE) inhibitory activity. J. Korean Soc. Food Sci. Nutr. 35, 307-314. doi: 10.3746/jkfn.2006.35.3.307

Chambial, S., Dwivedi, S., Shukla, K. K., John, P. J., and Sharma, P. (2013). Vitamin $\mathrm{C}$ in disease prevention and cure: an overview. Indian J. Clin. Biochem. 28, 314-328. doi: 10.1007/s12291-013-0375-3

Chen, C., Pearson, A. M., and Gray, J. I. (1992). Effects of synthetic antioxidants (BHA. BHT and PG) on the mutagenicity of IQ-like compounds. Food Chem. 43, 177-183. doi: 10.1016/0308-8146(92)90170-7

Chen, Y., Lin, H., Li, Z., and Mou, Q. (2015). The anti-allergic activity of polyphenol extracted from five marine algae. J. Ocean Univ. China 14, 681-684. doi: 10.1007/s11802-015-2601-5

Chin, Y. X., Lim, P. E., Maggs, C. A., Phang, S. M., Sharifuddin, Y., and Green, B. D. (2015). Anti-diabetic potential of selected Malaysian seaweeds. J. Appl. Phycol. 27, 2137-2148. doi: 10.1007/s10811-014-0462-8

Cho, H. M., Doan, T. P., Ha, T. K. Q., Kim, H. W., Lee, B. W., Pham, H. T. T., et al. (2019). Dereplication by high-performance liquid chromatography (HPLC) with quadrupole-time-of-flight mass spectroscopy (qTOF-MS) and antiviral activities of phlorotannins from Ecklonia cava. Mar. Drugs 17:149. doi: 10.3390/ md17030149

Cho, M., Lee, D. J., Kim, J. K., and You, S. (2014). Molecular characterization and immunomodulatory activity of sulfatedfucans from Agarum cribrosum. Carbohydr. Polym. 113, 507-514. doi: 10.1016/j.carbpol.2014.07.055

Cho, S., Yang, H., Jeon, Y. J., Lee, C. J., Jin, Y. H., Baek, N. I., et al. (2012). Phlorotannins of the edible brown seaweed Ecklonia cava Kjellman induce sleep via positive allosteric modulation of gamma-aminobutyric acid type Abenzodiazepine receptor: a novel neurological activity of seaweed polyphenols. Food Chem. 132, 1133-1142. doi: 10.1016/j.foodchem.2011.08.040

Chojnacka, K., Saeid, A., Witkowska, Z., and Tuhy, L. (2012). Biologically active compounds in seaweed extracts-the prospects for the application. Open Conf. Proc. J. 3, 20-28. doi: 10.2174/1876326X01203020020

Cirne-Santos, C. C., Barros, C. D. S., Gomes, M. W., Gomes, R., Cavalcanti, D. N., Obando, J. M., et al. (2019). In Vitro Antiviral Activity Against Zika Virus From a Natural Product of the Brazilian Brown Seaweed Dictyota menstrualis. Nat. Prod. Commun. 14:1934578X19859128. doi: 10.1177/1934578X19859128

Cirne-Santos, C. C., de Souza Barros, C., de Oliveira, M. C., Rabelo, V. W. H., Azevedo, R. C., Teixeira, V. L., et al. (2020). In vitro Studies on The Inhibition of Replication of Zika and Chikungunya Viruses by Dolastane Isolated from Seaweed Canistrocarpus cervicornis. Sci. Rep. 10:8263 . doi: 10.1038/s41598020-65357-7

Cirne-Santos, C. C., de Souza Barros, C., Nogueira, C. C. R., Amorim, L. D. S. C., de Mendonça Campos, R., Ratcliffe, N. A., et al. (2018). Antiviral effect of the seaweed Osmundaria obtusiloba against the Zika virus. J. Med. Plants Res. 12, 387-395. doi: 10.5897/JMPR2018.6624

Cosenza, V. A., Navarro, D. A., Ponce, N. M., and Stortz, C. A. (2017). “Seaweed polysaccharides: structure and applications," in Industrial Applications of Renewable Biomass Products, eds S. Goyanes and N. D'Accorso (Cham: Springer), 75-116. doi: 10.1007/978-3-319-61288-1_3

Costa, L. S., Fidelis, G. P., Cordeiro, S. L., Oliveira, R. M., Sabry, D. D. A., Câmara, R. B. G., et al. (2010). Biological activities of sulfated polysaccharides from 
tropical seaweeds. Biomed. Pharmacother. 64, 21-28. doi: 10.1016/j.biopha. 2009.03.005

Costa, L. S., Fidelis, G. P., Telles, C. B. S., Dantas-Santos, N., Camara, R. B. G., Cordeiro, S. L., et al. (2011). Antioxidant and antiproliferative activities of heterofucans from the seaweed Sargassum filipendula. Mar. Drugs 9, 952-966. doi: $10.3390 / \mathrm{md} 9060952$

Cotas, J., Leandro, A., Pacheco, D., Gonçalves, A. M., and Pereira, L. (2020). A Comprehensive Review of the Nutraceutical and Therapeutic Applications of Red Seaweeds (Rhodophyta). Life 10:19. doi: 10.3390/life10030019

da Silva Chagas, F. D., Lima, G. C., dos Santos, V. I. N., Costa, L. E. C., de Sousa, W. M., et al. (2020). Sulfated polysaccharide from the red algae Gelidiella acerosa: anticoagulant, antiplatelet and antithrombotic effects. Int. J. Biol. Macromol. 159, 415-421. doi: 10.1016/j.ijbiomac.2020.05.012

de Carvalho, M. M., de Freitas, R. A., Ducatti, D. R., Ferreira, L. G., Gonçalves, A. G., Colodi, F. G., et al. (2018). Modification of ulvans via periodate-chlorite oxidation: chemical characterization and anticoagulant activity. Carbohydr. Polym. 197, 631-640. doi: 10.1016/j.carbpol.2018. 06.041

de Quirós, A. R. B., Frecha-Ferreiro, S., Vidal-Pérez, A. M., and López-Hernández, J. (2010). Antioxidant compounds in edible brown seaweeds. Eur. Food Res. Technol. 231, 495-498. doi: 10.1007/s00217-010-1295-6

de Sousa Pinheiro, T., Santos, M. D. S. N., Castro, L. S. E. W., Paiva, A. A. D. O., Alves, L. G., Cruz, A. K. M., et al. (2017). A fucan of a brown seaweed and its antitumoral property on HT-29 and immunomodulatory activity in murine RAW 264. 7 macrophage cell line. J. Appl. Phycol. 29, 2061-2075. doi: 10.1007/ s10811-017-1075-9

de Souza, M. C. R., Marques, C. T., Dore, C. M. G., da Silva, F. R. F., Rocha, H. A. O., and Leite, E. L. (2007). Antioxidant activities of sulfated polysaccharides from brown and red seaweeds. J. Appl. Phycol. 19, 153-160. doi: 10.1007/s10811-0069121-z

De Zoysa, M., Nikapitiya, C., Jeon, Y. J., Jee, Y., and Lee, J. (2008). Anticoagulant activity of sulfated polysaccharide isolated from fermented brown seaweed Sargassum fulvellum. J. Appl. Phycol. 20, 67-74. doi: 10.1007/s10811-0079182-7

Denis, C., Morançais, M., Li, M., Deniaud, E., Gaudin, P., Wielgosz-Collin, G., et al. (2010). Study of the chemical composition of edible red macroalgae Grateloupia turuturu from Brittany (France). Food Chem. 119, 913-917. doi: 10.1016/j.foodchem.2009.07.047

Ding, K., Zhang, B., Chen, X., Xu, Y., Huang, C., Jin, C., et al. (2021). Structural characterization of cocktail-like targeting polysaccharides from Ecklonia kurome Okam and their anti-SARS-CoV-2 activities in vitro. bioRxiv [Preprint]. doi: 10.1101/2021.01.14.426521

Dutot, M., Fagon, R., Hemon, M., and Rat, P. (2012). Antioxidant, antiinflammatory, and anti-senescence activities of a phlorotannin-rich natural extract from brown seaweed Ascophyllum nodosum. Appl. Biochem. Biotechnol. 167, 2234-2240. doi: 10.1007/s12010-012-9761-1

Ehrlich, P. R., and Harte, J. (2015). Opinion: to feed the world in 2050 will require a global revolution. Proc. Natl. Acad. Sci. U. S. A. 112, 14743-14744. doi: $10.1073 /$ pnas.1519841112

Enrique, C., and Lester, P. (2002). Handbook of antioxidants. New York: Marcel Dekker.

Falquet, J., and Hurni, J. P. (1997). The nutritional aspects of Spirulina. Antenna Foundation. Available online at: https://www.antenna.ch/wp-content/uploads/ 2017/03/AspectNut_UK.pdf (Accessed July 25, 2017)

Fernández-López, J. A., Fernández-Lledó, V., and Angosto, J. M. (2020). New insights into red plant pigments: more than just natural colorants. RSC $A d v$. 10, 24669-24682. doi: 10.1039/D0RA03514A

Ferruzzi, M. G., and Blakeslee, J. (2007). Digestion, absorption, and cancer preventative activity of dietary chlorophyll derivatives. Nutr. Res. 27, 1-12. doi: 10.1016/j.nutres.2006.12.003

Fitzgerald, C., Aluko, R. E., Hossain, M., Rai, D. K., and Hayes, M. (2014). Potential of a renin inhibitory peptide from the red seaweed Palmaria palmata as a functional food ingredient following confirmation and characterization of a hypotensive effect in spontaneously hypertensive rats. J. Agric. Food Chem. 62, 8352-8356. doi: 10.1021/jf500983n

Fleurence, J. (1999). Seaweed proteins: biochemical, nutritional aspects and potential uses. Trends Food Sci. Technol. 10, 25-28. doi: 10.1016/S09242244(99)00015-1
Francavilla, M., Franchi, M., Monteleone, M., and Caroppo, C. (2013). The red seaweed Gracilaria gracilis as a multi products source. Mar. Drugs 11, 37543776. doi: $10.3390 / \mathrm{md} 11103754$

Fröde, T. S., and Medeiros, Y. S. (2008). Animal models to test drugs with potential antidiabetic activity. J. Ethnopharmacol. 115, 173-183. doi: 10.1016/j.jep.2007. 10.038

Galasso, C., Corinaldesi, C., and Sansone, C. (2017). Carotenoids from marine organisms: biological functions and industrial applications. Antioxidants 6:96. doi: 10.3390/antiox6040096

Ganesan, A. R., Tiwari, U., and Rajauria, G. (2019). Seaweed nutraceuticals and their therapeutic role in disease prevention. Food Sci. Hum. Wellness 8, 252-263. doi: 10.1016/j.fshw.2019.08.001

Ganesan, P., Kumar, C. S., and Bhaskar, N. (2008). Antioxidant properties of methanol extract and its solvent fractions obtained from selected Indian red seaweeds. Bioresour. Technol. 99, 2717-2723. doi: 10.1016/j.biortech.2007. 07.005

Gautam, P. K., Deepak, P., Kumar, S., and Acharya, A. (2013). Role of macrophage in tumor microenvironment: prospect in cancer immunotherapy. Eur. J. Inflamm. 11, 1-14. doi: 10.1177/1721727X1301100101

Generalić Mekinić, I., Skroza, D., Šimat, V., Hamed, I., Čagalj, M., and PopovićPerković, Z. (2019). Phenolic content of brown algae (Pheophyceae) species: extraction, identification, and quantification. Biomolecules 9:244. doi: 10.3390/biom 9060244

Gómez-Guzmán, M., Rodríguez-Nogales, A., Algieri, F., and Gálvez, J. (2018). Potential role of seaweed polyphenols in cardiovascular-associated disorders. Mar. Drugs 16:250. doi: 10.3390/md16080250

Gómez-Ordóñez, E., Jiménez-Escrig, A., and Rupérez, P. (2010). Dietary fibre and physicochemical properties of several edible seaweeds from the northwestern Spanish coast. Food Res. Int. 43, 2289-2294. doi: 10.1016/j.foodres.2010.08.005

Gonçalves-Fernández, C., Sineiro, J., Moreira, R., and Gualillo, O. (2019). Extraction and characterization of phlorotannin-enriched fractions from the Atlantic seaweed Bifurcaria bifurcata and evaluation of their cytotoxic activity in murine cell line. J. Appl. Phycol. 31, 2573-2583. doi: 10.1007/s10811-0181729-2

Gosch, B. J., Paul, N. A., de Nys, R., and Magnusson, M. (2015). Seasonal and within-plant variation in fatty acid content and composition in the brown seaweed Spatoglossum macrodontum (Dictyotales. Phaeophyceae). J. Appl. Phycol. 27, 387-398. doi: 10.1007/s10811-014-0308-4

Gropper, S. S., and Smith, J. L. (2012). Advanced nutrition and human metabolism. Boston: Cengage Learning.

Gupta, M., Aggarwal, R., Raina, N., and Khan, A. (2020). "Vitamin-Loaded Nanocarriers as Nutraceuticals in Healthcare Applications," in Nanomedicine for Bioactives, ed. M. Rahman (Singapore: Springer), 451-470. doi: 10.1007/ 978-981-15-1664-1_18

Gupta, S., and Abu-Ghannam, N. (2011). Bioactive potential and possible health effects of edible brown seaweeds. Trends Food Sci. Technol. 22, 315-326. doi: 10.1016/j.tifs.2011.03.011

Hernández-Carmona, G., Carrillo-Domínguez, S., Arvizu-Higuera, D. L., Rodríguez-Montesinos, Y. E., Murillo-Álvarez, J. I., Muñoz-Ochoa, M., et al. (2009). Monthly variation in the chemical composition of Eisenia arborea JE Areschoug. J. Appl. Phycol. 21, 607-616. doi: 10.1007/s10811-009-9454-5

Hirayama, D., Iida, T., and Nakase, H. (2018). The phagocytic function of macrophage-enforcing innate immunity and tissue homeostasis. Int. J. Mol. Sci. 19:92. doi: 10.3390/ijms19010092

Holdt, S. L., and Kraan, S. (2011). Bioactive compounds in seaweed: functional food applications and legislation. J. Appl. Phycol. 23, 543-597. doi: 10.1007/s10811010-9632-5

Holland, B., Brown, J., and Buss, D. H. (1993). Fish and fish products: third supplement to the fifth edition of McCance and Widdowson's' The composition offoods. Cambridge: Royal Society of Chemistry (RSC).

Islamian, J. P., and Mehrali, H. (2015). Lycopene as a carotenoid provides radio protectant and antioxidant effects by quenching radiation-induced free radical singlet oxygen: an overview. Cell 16:386. doi: 10.22074/cellj.2015.485

Ito, K., and Hori, K. (1989). Seaweed: chemical composition and potential food uses. Food Rev. Int. 5, 101-144. doi: 10.1080/87559128909540845

Iwai, K. (2008). Antidiabetic and antioxidant effects of polyphenols in brown alga Ecklonia stolonifera in genetically diabetic KK-A y mice. Plant Foods Hum. Nutr. 63:163. doi: 10.1007/s11130-008-0098-4 
Jaballi, I., Sallem, I., Feki, A., Cherif, B., Kallel, C., Boudawara, O., et al. (2019). Polysaccharide from a Tunisian red seaweed Chondrus canaliculatus: structural characteristics, antioxidant activity and in vivo hemato-nephroprotective properties on maneb induced toxicity. Int. J. Biol. Macromol. 123, 1267-1277. doi: 10.1016/j.ijbiomac.2018.12.048

Jaspars, M., and Folmer, F. (2013). Sea Vegetables for Health: Food and Health Innovation Service (FHIS). Aberdeen: University of Aberdeen

Jesumani, V., Du, H., Aslam, M., Pei, P., and Huang, N. (2019). Potential Use of Seaweed Bioactive Compounds in Skincare- A Review. Mar. Drugs 17:688. doi: $10.3390 / \mathrm{md} 17120688$

Jia, R. B., Wu, J., Li, Z. R., Ou, Z. R., Lin, L., Sun, B., et al. (2020). Structural characterization of polysaccharides from three seaweed species and their hypoglycemic and hypolipidemic activities in type 2 diabetic rats. Int. J. Biol. Macromol. 155, 1040-1049. doi: 10.1016/j.ijbiomac.2019.11.068

Jiao, G., Yu, G., Wang, W., Zhao, X., Zhang, J., and Ewart, S. H. (2012). Properties of polysaccharides in several seaweeds from Atlantic Canada and their potential anti-influenza viral activities. J. Ocean Univ. China 11, 205-212. doi: 10.1007/ s11802-012-1906-x

Jiménez-Escrig, A., Gómez-Ordóñez, E., and Rupérez, P. (2011). Seaweed as a source of novel nutraceuticals: sulfated polysaccharides and peptides. Adv. Food Nutr. Res. 64, 325-337. doi: 10.1016/B978-0-12-387669-0.00026-0

Jiménez-Escrig, A., Gómez-Ordóñez, E., and Rupérez, P. (2012). Brown and red seaweeds as potential sources of antioxidant nutraceuticals. J. Appl. Phycol. 24, 1123-1132. doi: 10.1007/s10811-011-9742-8

Jiménez-Escrig, A., and Sánchez-Muniz, F. J. (2000). Dietary fibre from edible seaweeds: chemical structure, physicochemical properties and effects on cholesterol metabolism. Nutr. Res. 20, 585-598. doi: 10.1016/S0271-5317(00) 00149-4

Jin, W., Zhang, Q., Wang, J., and Zhang, W. (2013). A comparative study of the anticoagulant activities of eleven fucoidans. Carbohydr. Polym. 91, 1-6. doi: 10.1016/j.carbpol.2012.07.067

Jintang, S., Alei, F., Yun, Z., Shanzhen, S., Weixu, H., Meixiang, Y., et al. (2010). Fucoidan increases TNF- $\alpha$-induced MMP-9 secretion in monocytic cell line U937. Inflamm. Res. 59, 271-276. doi: 10.1007/s00011-009-0095-6

Johnston, G. A. (2015). Flavonoid nutraceuticals and ionotropic receptors for the inhibitory neurotransmitter GABA. Neurochem. Int. 89, 120-125. doi: 10.1016/ j.neuint.2015.07.013

Jung, H. A., Hyun, S. K., Kim, H. R., and Choi, J. S. (2006). Angiotensin-converting enzyme I inhibitory activity of phlorotannins from Ecklonia stolonifera. Fish. Sci. 72, 1292-1299. doi: 10.1111/j.1444-2906.2006.01288.x

Kadam, S. U., Álvarez, C., Tiwari, B. K., and O’Donnell, C. P. (2017). Extraction and characterization of protein from Irish brown seaweed Ascophyllum nodosum. Food Res. Int. 99, 1021-1027. doi: 10.1016/j.foodres.2016.07.018

Khan, W., Rayirath, U. P., Subramanian, S., Jithesh, M. N., Rayorath, P., Hodges, D. M., et al. (2009). Seaweed extracts as biostimulants of plant growth and development. J. Plant Growth Regul. 28, 386-399. doi: 10.1007/s00344-0099103-x

Kharkwal, H., Joshi, D. D., Panthari, P., Pant, M. K., and Kharkwal, A. C. (2012). Algae as future drugs. Asian J. Pharm. Clin. Res. 5, 1-4.

Kılınç, B., Cirik, S., Turan, G., Tekogul, H., and Koru, E. (2013). "Seaweeds for food and industrial applications," in Food industry, ed. I. Muzzalupo (London: IntechOpen), doi: 10.5772/53172

Kim, J. K., Cho, M. L., Karnjanapratum, S., Shin, I. S., and You, S. G. (2011). In vitro and in vivo immunomodulatory activity of sulfated polysaccharides from Enteromorpha prolifera. Int. J. Biol. Macromol. 49, 1051-1058. doi: 10. 1016/j.ijbiomac.2011.08.032

Kim, S. K., and Wijesekara, I. (2010). Development and biological activities of marine-derived bioactive peptides: a review. J. Funct. Foods 2, 1-9. doi: 10.1016/ j.jff.2010.01.003

Kimiya, T., Ohtani, K., Satoh, S., Abe, Y., Ogita, Y., Kawakita, H., et al. (2008). Inhibitory effects of edible marine algae extracts on degranulation of RBL-2H3 cells and mouse eosinophils. Fish. Sci. 74, 1157-1165. doi: 10.1111/j.1444-2906. 2008.01635.x

Ko, S. C., Kang, M. C., Kang, N., Kim, H. S., Lee, S. H., Ahn, G., et al. (2017). Effect of angiotensin I-converting enzyme (ACE) inhibition and nitric oxide (NO) production of 6,6'-bieckol, a marine algal polyphenol and its anti-hypertensive effect in spontaneously hypertensive rats. Process Biochem. 58, 326-332. doi: 10.1016/j.procbio.2017.04.014

Ko, S. C., Lee, M., Lee, J. H., Lee, S. H., Lim, Y., and Jeon, Y. J. (2013). Dieckol, a phlorotannin isolated from a brown seaweed, Ecklonia cava, inhibits adipogenesis through AMP-activated protein kinase (AMPK) activation in 3T3L1 preadipocytes. Environ. Toxicol. Pharmacol. 36, 1253-1260. doi: 10.1016/j. etap.2013.10.011

Kraan, S. (2012). "Algal polysaccharides, novel applications and outlook," in Carbohydrates-comprehensive studies on glycobiology and glycotechnology, ed. C. F. Chang (Singapore: IntechOpen). doi: 10.5772/51572

Krylova, N. V., Ermakova, S. P., Lavrov, V. F., Leneva, I. A., Kompanets, G. G., Iunikhina, O. V., et al. (2020). The comparative analysis of antiviral activity of native and modified fucoidans from brown algae Fucus evanescens in vitro and in vivo. Mar. Drugs 18:224. doi: 10.3390/md18040224

Kuda, T., and Ikemori, T. (2009). Minerals, polysaccharides and antioxidant properties of aqueous solutions obtained from macroalgal beach-casts in the Noto Peninsula, Ishikawa, Japan. Food Chem. 112, 575-581. doi: 10.1016/j. foodchem.2008.06.008

Kudus, K., Grasian, I., Madasamy, S., and John, A. (2017). Immunomodulatory effect of alginic acid from brown seaweed sargassum wightii on disease resistance in penaeus monodon. J. Clean WAS 1, 26-29.

Kumar, C. S., Ganesan, P., Suresh, P. V., and Bhaskar, N. (2008). Seaweeds as a source of nutritionally beneficial compounds-a review. J. Food Sci. Technol. 45:1.

Kumar, M., Kumari, P., Trivedi, N., Shukla, M. K., Gupta, V., Reddy, C. R. K., et al. (2011). Minerals, PUFAs and antioxidant properties of some tropical seaweeds from Saurashtra coast of India. J. Appl. Phycol. 23, 797-810. doi: 10.1007/s10811-010-9578-7

Kwon, P. S., Oh, H., Kwon, S. J., et al. (2020). Sulfated polysaccharides effectively inhibit SARS-CoV-2 in vitro. Cell Discov. 6:50. doi: 10.1038/s41421-02000192-8

Lafarga, T., Acién-Fernández, F. G., and Garcia-Vaquero, M. (2020). Bioactive peptides and carbohydrates from seaweed for food applications: natural occurrence, isolation, purification, and identification. Algal Res. 48:101909. doi: 10.1016/j.algal.2020.101909

Landefeld, C. S., and Beyth, R. J. (1993). Anticoagulant-related bleeding: clinical epidemiology, prediction, and prevention. Am. J. Med. 95, 315-328. doi: 10. 1016/0002-9343(93)90285-W

Lee, J. B., Ohta, Y., Hayashi, K., and Hayashi, T. (2010). Immunostimulating effects of a sulphated galactan from Codium fragile. Carbohydr. Res. 345, 1452-1454. doi: 10.1016/j.carres.2010.02.026

Lee, S. Y., and Hur, S. J. (2017). Antihypertensive peptides from animal products, marine organisms, and plants. Food Chem. 228, 506-517. doi: 10.1016/j. foodchem.2017.02.039

Leonard, S. G., Sweeney, T., Pierce, K. M., Bahar, B., Lynch, B. P., and O’Doherty, J. V. (2010). The effects of supplementing the diet of the sow with seaweed extracts and fish oil on aspects of gastrointestinal health and performance of the weaned piglet. Livest. Sci. 134, 135-138. doi: 10.1016/j.livsci.2010. 06.118

Li, B., Lu, F., Wei, X., and Zhao, R. (2008). Fucoidan: structure and bioactivity. Molecules 13, 1671-1695. doi: 10.3390/molecules13081671

Li, Y., Fu, X., Duan, D., Liu, X., Xu, J., and Gao, X. (2017). Extraction and identification of phlorotannins from the brown alga, Sargassum fusiforme (Harvey) Setchell. Mar. Drugs 15:49. doi: 10.3390/md15020049

Li, Y., Sadiq, F. A., Fu, L., Zhu, H., Zhong, M., and Sohail, M. (2016). Identification of angiotensin I-converting enzyme inhibitory peptides derived from enzymatic hydrolysates of razor clam sinonovacula constricta. Mar. Drugs 14:110. doi: $10.3390 / \mathrm{md} 14060110$

Li, Y. X., and Kim, S. K. (2011). Utilization of seaweed derived ingredients as potential antioxidants and functional ingredients in the food industry: an overview. Food Sci. Biotechnol. 20, 1461-1466. doi: 10.1007/s10068-011-0202-7

Lordan, S., Smyth, T. J., Soler-Vila, A., Stanton, C., and Ross, R. P. (2013). The $\alpha$-amylase and $\alpha$-glucosidase inhibitory effects of Irish seaweed extracts. Food Chem. 141, 2170-2176. doi: 10.1016/j.foodchem.2013.04.123

Mabeau, S., and Fleurence, J. (1993). Seaweed in food products: biochemical and nutritional aspects. Trends Food Sci. Technol. 4, 103-107. doi: 10.1016/09242244(93)90091-N

MacArtain, P., Gill, C. I., Brooks, M., Campbell, R., and Rowland, I. R. (2007). Nutritional value of edible seaweeds. Nutr. Rev. 65, 535-543. doi: 10.1111/j. 1753-4887.2007.tb00278.x

Magalhaes, K. D., Costa, L. S., Fidelis, G. P., Oliveira, R. M., Nobre, L. T. D. B., Dantas-Santos, N., et al. (2011). Anticoagulant, antioxidant and antitumor activities of heterofucans from the seaweed Dictyopteris delicatula. Int. J. Mol. Sci. 12, 3352-3365. doi: 10.3390/ijms12053352 
Makarenkova, I. D., Logunov, D. Y., Tukhvatulin, A. I., Semenova, I. B., Besednova, N. N., and Zvyagintseva, T. N. (2012). Interactions between sulfated polysaccharides from sea brown algae and Toll-like receptors on HEK293 eukaryotic cells in vitro. Bull. Exp. Biol. Med. 154, 241-244. doi: 10.1007/ s10517-012-1922-2

Manandhar, B., Wagle, A., Seong, S. H., Paudel, P., Kim, H. R., Jung, H. A., et al. (2019). Phlorotannins with potential anti-tyrosinase and antioxidant activity isolated from the marine seaweed Ecklonia stolonifera. Antioxidants 8:240. doi: $10.3390 /$ antiox 8080240

Mandal, P., Mateu, C. G., Chattopadhyay, K., Pujol, C. A., Damonte, E. B., and Ray, B. (2007). Structural features and antiviral activity of sulphated fucans from the brown seaweed Cystoseira indica. Antivir. Chem. Chemother. 18, 153-162. doi: $10.1177 / 095632020701800305$

Maneesh, A., and Chakraborty, K. (2018). Pharmacological potential of sulfated polygalactopyranosyl-fucopyranan from the brown seaweed Sargassum wightii. J. Appl. Phycol. 30, 1971-1988. doi: 10.1007/s10811-017-1385-y

Maneesh, A., Chakraborty, K., and Makkar, F. (2017). Pharmacological activities of brown seaweed Sargassum wightii (Family Sargassaceae) using different in vitro models. Int. J. Food Prop. 20, 931-945. doi: 10.1080/10942912.2016.1189434

Manggau, M., Hamzah, M., Mamada, S., Nurdin, W. B., and Zaenuddin, E. N. (2019). Anti coagulant activities of Brown Seaweed Sargassum cristaefolium Extract. J. Phys. Conf. Ser. 1341:072006. doi: 10.1088/1742-6596/1341/7/072006

Manivasagan, P., Bharathiraja, S., SanthaMoorthy, M., Mondal, S., Seo, H., Dae Lee, $\mathrm{K}$., et al. (2018). Marine natural pigments as potential sources for therapeutic applications. Crit. Rev. Biotechnol. 38, 745-761. doi: 10.1080/07388551.2017. 1398713

Martin, M., and Deussen, A. (2019). Effects of natural peptides from food proteins on angiotensin converting enzyme activity and hypertension. Crit. Rev. Food Sci. Nutr. 59, 1264-1283. doi: 10.1080/10408398.2017.1402750

Martins, C. D. L., Ramlov, F., Carneiro, N. P. N., Gestinari, L. M., dos Santos, B. F., Bento, L. M., et al. (2013). Antioxidant properties and total phenolic contents of some tropical seaweeds of the Brazilian coast. J. Appl. Phycol. 25, 1179-1187. doi: 10.1007/s10811-012-9918-x

Mathew, S., and Ravishankar, C. N. (2018). Seaweeds as a source of micro and macro nutrients. Cochin: ICAR-Central Institute of Fisheries Technology.

Mendes Marques, M. L., Presa, F. B., Viana, R. L. S., Costa, M. S. S. P., Amorim, M. O. R., Bellan, D. L., et al. (2019). Anti-thrombin, anti-adhesive, anti-migratory, and anti-proliferative activities of sulfated galactans from the tropical green seaweed, Udotea flabellum. Mar. Drugs 17:5. doi: 10.3390/ $\operatorname{md} 17010005$

Mihova, S. G., Georgiev, D. I., Minkova, K. M., and Tchernov, A. A. (1996). Phycobiliproteins in Rhodellareticulata and photoregulatory effects on their content. J. Biotechnol. 48, 251-257. doi: 10.1016/0168-1656(96)01515-5

Mohapatra, L., Bhattamisra, S. K., Panigrahy, R. C., and Parida, S. K. (2016). Evaluation of the Antioxidant, Hypoglycaemic and Anti-diabetic Activities of Some Seaweed Collected From the East Coast of India. Biomed. Pharmacol. J. 9, 365-375. doi: 10.13005/bpj/948

Murata, M., and Nakazoe, J. I. (2001). Production and use of marine aIgae in Japan. Jpn. Agric. Res. Q. 35, 281-290. doi: 10.6090/jarq.35.281

Na, H. J., Moon, P. D., Ko, S. G., Lee, H. J., Jung, H. A., Hong, S. H., et al. (2005a). Sargassum hemiphyllum inhibits atopic allergic reaction via the regulation of inflammatory mediators. J. Pharmacol. Sci. 97, 219-226. doi: 10.1254/jphs. fp0040326

Na, H. J., Moon, P. D., Lee, H. J., Kim, H. R., Chae, H. J., Shin, T., et al. (2005b). Regulatory effect of atopic allergic reaction by Carpopeltis affinis. J. Ethnopharmacol. 101, 43-48. doi: 10.1016/j.jep.2005.03.026

Namvar, F., Mohamad, R., Baharara, J., Zafar-Balanejad, S., Fargahi, F., and Rahman, H. S. (2013). Antioxidant, antiproliferative, and antiangiogenesis effects of polyphenol-rich seaweed (Sargassum muticum). Biomed Res. Int. 2013:604787. doi: 10.1155/2013/604787

Namvar, F., Mohamed, S., Fard, S. G., Behravan, J., Mustapha, N. M., Alitheen, N. B. M., et al. (2012). Polyphenol-rich seaweed (Eucheuma cottonii) extract suppresses breast tumour via hormone modulation and apoptosis induction. Food Chem. 130, 376-382. doi: 10.1016/j.foodchem.2011.07.054

Narayani, S. S., Saravanan, S., Ravindran, J., Ramasamy, M. S., and Chitra, J. (2019). In vitro anticancer activity of fucoidan extracted from Sargassum cinereum against Caco-2 cells. Int. J. Biol. Macromol. 138, 618-628. doi: 10.1016/j. ijbiomac.2019.07.127
Neumann, U., Derwenskus, F., FlaizFlister, V., Schmid-Staiger, U., Hirth, T., and Bischoff, S. C. (2019). Fucoxanthin, a carotenoid derived from Phaeodactylum tricornutum exerts antiproliferative and antioxidant activities in vitro. Antioxidants 8:183. doi: 10.3390/antiox 8060183

Norziah, M. H., and Ching, C. Y. (2000). Nutritional composition of edible seaweed Gracilaria changgi. Food Chem. 68, 69-76. doi: 10.1016/S0308-8146(99) 00161-2

O'Doherty, J. V., Dillon, S., Figat, S., Callan, J. J., and Sweeney, T. (2010). The effects of lactose inclusion and seaweed extract derived from Laminaria spp. on performance, digestibility of diet components and microbial populations in newly weaned pigs. Anim. Feed Sci. Technol. 157, 173-180. doi: 10.1016/j. anifeedsci.2010.03.004

Okai, Y., Higashi-Okai, K., Yano, Y., and Otani, S. (1996). Identification of antimutagenic substances in an extract of edible red alga, Porphyra tenera (Asadusa-nori). Cancer Lett. 100, 235-240. doi: 10.1016/0304-3835(95) 04101-X

Okuzumi, J., Takahashi, T., Yamane, T., Kitao, Y., Inagake, M., Ohya, K., et al. (1993). Inhibitory effects of fucoxanthin, a natural carotenoid, on N-ethylN'-nitro-N-nitrosoguanidine-induced mouse duodenal carcinogenesis. Cancer Lett. 68, 159-168. doi: 10.1016/0304-3835(93)90142-V

Olivares-Bañuelos, T., Gutiérrez-Rodríguez, A. G., Méndez-Bellido, R., TovarMiranda, R., Arroyo-Helguera, O., Juárez-Portilla, C., et al. (2019). Brown seaweed Egregia menziesii's cytotoxic activity against brain cancer cell lines. Molecules 24:260. doi: 10.3390/molecules24020260

Ortiz, J., Romero, N., Robert, P., Araya, J., Lopez-Hernández, J., Bozzo, C., et al. (2006). Dietary fiber, amino acid, fatty acid and tocopherol contents of the edible seaweeds Ulva lactuca and Durvillaea antarctica. Food Chem. 99, 98-104. doi: 10.1016/j.foodchem.2005.07.027

Pádua, D., Rocha, E., Gargiulo, D., and Ramos, A. A. (2015). Bioactive compounds from brown seaweeds: phloroglucinol, fucoxanthin and fucoidan as promising therapeutic agents against breast cancer. Phytochem. Lett. 14, 91-98. doi: 10. 1016/j.phytol.2015.09.007

Palanisamy, S. K., Arumugam, V., Rajendran, S., Ramadoss, A., Nachimuthu, S., Peter, D. M., et al. (2019). Chemical diversity and anti-proliferative activity of marine algae. Nat. Prod. Res. 33, 2120-2124. doi: 10.1080/14786419.2018. 1488701

Pangestuti, R., Getachew, A. T., Siahaan, E. A., and Chun, B. S. (2019). Characterization of functional materials derived from tropical red seaweed Hypnea musciformis produced by subcritical water extraction systems. J. Appl. Phycol. 31, 2517-2528. doi: 10.1007/s10811-019-1754-9

Pangestuti, R., and Kim, S. K. (2015). "Seaweed proteins, peptides, and amino acids," in Seaweed Sustainability, eds B. K. Tiwari, D. J. Troy (Cambridge: Academic Press), 125-140. doi: 10.1016/B978-0-12-418697-2.00006-4

Parvez, M. K., Rehman, M. T., Alam, P., Al-Dosari, M. S., Alqasoumi, S. I., and Alajmi, M. F. (2019). Plant-derived antiviral drugs as novel hepatitis B virus inhibitors: cell culture and molecular docking study. Saudi Pharm. J. 27, 389-400. doi: 10.1016/j.jsps.2018.12.008

Pereira, D. M., Valentão, P., and Andrade, P. B. (2014). Marine natural pigments: chemistry, distribution and analysis. Dyes Pigm. 111, 124-134. doi: 10.1016/j. dyepig.2014.06.011

Pereira, L. (2011). "A review of the nutrient composition of selected edible seaweeds," in Seaweed: Ecology, nutrient composition and medicinal uses, ed. V. H. Pomin (Coimbra: Nova Science Publishers, Inc), 15-47.

Pereira, L., and Critchley, A. T. (2020). The COVID 19 novel coronavirus pandemic 2020: seaweeds to the rescue? Why does substantial, supporting research about the antiviral properties of seaweed polysaccharides seem to go unrecognized by the pharmaceutical community in these desperate times?. J. Appl. Phycol. 32, 1875-1877. doi: 10.1007/s10811-020-02143-y

Pérez-Recalde, M., Matulewicz, M. C., Pujol, C. A., and Carlucci, M. J. (2014). In vitro and in vivo immunomodulatory activity of sulfated polysaccharides from red seaweed Nemalion helminthoides. Int. J. Biol. Macromol. 63, 38-42. doi: 10.1016/j.ijbiomac.2013.10.024

Praiboon, J., Palakas, S., Noiraksa, T., and Miyashita, K. (2018). Seasonal variation in nutritional composition and anti-proliferative activity of brown seaweed, Sargassum oligocystum. J. Appl. Phycol. 30, 101-111. doi: 10.1007/s10811-0171248-6

Prasedya, E., Hamdin, C. D., Riandinata, S. K., Miyake, M., Kobayashi, D., Hazama, A., et al. (2019). "Evaluation of seaweed Gelidium latifolium as potential 
medicinal food," in Proceedings of the 23rd International Seaweed Symposium, (Jeju: International Convention Center), 152-153.

Ragan, M. A., and Jensen, A. (1978). Quantitative studies on brown algal phenols. II. Seasonal variation in polyphenol content of Ascophyllum nodosum (L.) Le Jol. and Fucus vesiculosus (L.). J. Exp. Mar. Biol. Ecol. 34, 245-258. doi: 10.1016/ S0022-0981(78)80006-9

Rajapakse, N., and Kim, S. K. (2011). Nutritional and digestive health benefits of seaweed. Adv. Food Nutr. Res. 64, 17-28. doi: 10.1016/B978-0-12-387669-0. 00002-8

Rajauria, G. (2018). Optimization and validation of reverse phase HPLC method for qualitative and quantitative assessment of polyphenols in seaweed. J. Pharm. Biomed. Anal. 148, 230-237. doi: 10.1016/j.jpba.2017.10.002

Rajauria, G., and Abu-Ghannam, N. (2013). Isolation and partial characterization of bioactive fucoxanthin from Himanthalia elongata brown seaweed: a TLCbased approach. Int. J. Anal. Chem. 2013:6. doi: 10.1155/2013/802573

Ramirez-Higuera, A., Quevedo-Corona, L., Paniagua-Castro, N., ChamorroCeballos, G., Milliar-Garcia, A., and Jaramillo-Flores, M. E. (2014). Antioxidant enzymes gene expression and antihypertensive effects of seaweeds Ulva linza and Lessonia trabeculata in rats fed a high-fat and high-sucrose diet. J. Appl. Phycol. 26, 597-605. doi: 10.1007/s10811-013-0134-0

Rao, P. S., Mantri, V. A., and Ganesan, K. (2007). Mineral composition of edible seaweed Porphyra vietnamensis. Food Chem. 102, 215-218. doi: 10.1016/j. foodchem.2006.05.009

Rathore, S. S., Chaudhary, D. R., Boricha, G. N., Ghosh, A., Bhatt, B. P., Zodape, S. T., et al. (2009). Effect of seaweed extract on the growth, yield and nutrient uptake of soybean (Glycine max) under rainfed conditions. S. Afr. J. Bot. 75, 351-355. doi: 10.1016/j.sajb.2008.10.009

Rupérez, P., Ahrazem, O., and Leal, J. A. (2002). Potential antioxidant capacity of sulfated polysaccharides from the edible marine brown seaweed Fucus vesiculosus. J. Agric. Food Chem. 50, 840-845. doi: 10.1021/jf010908o

Salar, R. K., and Dhall, A. (2010). Antimicrobial and free radical scavenging activity of extracts of some Indian medicinal plants. J. Med. Plants Res. 4, 2313-2320. doi: 10.5897/JMPR10.155

Samee, H., Li, Z. X., Lin, H., Khalid, J., and Guo, Y. C. (2009). Anti-allergic effects of ethanol extracts from brown seaweeds. J. Zhejiang Univ. Sci. B 10:147. doi: $10.1631 /$ jzus.B0820185

Sánchez-Machado, D. I., López-Cervantes, J., Lopez-Hernandez, J., and PaseiroLosada, P. (2004). Fatty acids, total lipid, protein and ash contents of processed edible seaweeds. Food Chem. 85, 439-444. doi: 10.1016/j.foodchem.2003. 08.001

Sanger, G., Rarung, L. K., Damongilala, L. J., Kaseger, B. E., and Montolalu, L. A. D. Y. (2019). Phytochemical constituents and antidiabetic activity of edible marine red seaweed (Halymenia durvilae). IOP Conf. Ser. Earth Environ. Sci. 278:012069. doi: 10.1088/1755-1315/278/1/012069

Sanniyasi, E., Venkatasubramanian, G., Anbalagan, M. M., Raj, P. P., and Gopal, R. K. (2019). In vitro anti-HIV-1 activity of the bioactive compound extracted and purified from two different marine macroalgae (seaweeds) (Dictyota bartayesiana JV Lamouroux and Turbinaria decurrens Bory). Sci. Rep. 9:12185. doi: 10.1038/s41598-019-47917-8

Sato, M., Hosokawa, T., Yamaguchi, T., Nakano, T., Muramoto, K., Kahara, T., et al. (2002). Angiotensin I-converting enzyme inhibitory peptides derived from wakame (Undaria pinnatifida) and their antihypertensive effect in spontaneously hypertensive rats. J. Agric. Food Chem. 50, 6245-6252. doi: 10. 1021/jf020482t

Schubert, N., García-Mendoza, E., and Pacheco-Ruiz, I. (2006). Carotenoid composition of marine red algae. J. Phycol. 42, 1208-1216. doi: 10.1111/j.15298817.2006.00274.x

Shahidi, F., Zhong, H. J., and Ambigaipalan, P. (2005). Antioxidants: regulatory status. Bailey's Ind. Oil Fat Prod. 2005, 1-21. doi: 10.1002/047167849X.bio035. pub2

Sheih, I. C., Fang, T. J., Wu, T. K., and Lin, P. H. (2009). Anticancer and antioxidant activities of the peptide fraction from algae protein waste. J. Agric. Food Chem. 58, 1202-1207. doi: 10.1021/jf903089m

Sheih, I. C., Fang, T. J., Wu, T. K., and Lin, P. H. (2010). Anticancer and antioxidant activities of the peptide fraction from algae protein waste. J. Agric. Food Chem. 58, 1202-1207.

Shen, W., Wang, H., Guo, G., and Tuo, J. (2008). Immunomodulatory effects of Caulerpa racemosa varpeltata polysaccharide and its selenizing product on $\mathrm{T}$ lymphocytes and NK cells in mice. Sci. China Ser. C Life Sci. 51, 795-801. doi: 10.1007/s11427-008-0106-9

Shi, D., Li, J., Guo, S., Su, H., and Fan, X. (2009). The antitumor effect of bromophenol derivatives in vitro and Leathesia nana extract in vivo. Chin. J. Oceanol. Limnol. 27, 277-282. doi: 10.1007/s00343-009-9119-x

Shibata, T., Fujimoto, K., Nagayama, K., Yamaguchi, K., and Nakamura, T. (2002). Inhibitory activity of brown algal phlorotannins against hyaluronidase. Int. J. Food Sci. Technol. 37, 703-709. doi: 10.1046/j.1365-2621.2002.00603.x

Shibata, T., Ishimaru, K., Kawaguchi, S., Yoshikawa, H., and Hama, Y. (2007). "Antioxidant activities of phlorotannins isolated from Japanese Laminariaceae," in Nineteenth International Seaweed Symposium, eds M.A. Borowitzka, A.T. Critchley, S. Kraan, A. Peters (Dordrecht: Springer), 255-261. doi: 10.1007/9781-4020-9619-8_32

Shoeib, N. A., Bibby, M. C., Blunden, G., Linley, P. A., Swaine, D. J., Wheelhouse, R. T., et al. (2004). In-vitro Cytotoxic Activities of the Major Bromophenols of the Red Alga Polysiphonia lanosa and Some Novel Synthetic Isomers. J. Nat. Prod. 67, 1445-1449. doi: 10.1021/np0305268

Silva, T. M. A., Alves, L. G., De Queiroz, K. C. S., Santos, M. G. L., Marques, C. T., Chavante, S. F., et al. (2005). Partial characterization and anticoagulant activity of a heterofucan from the brown seaweed Padina gymnospora. Braz. J. Med. Biol. Res. 38, 523-533. doi: 10.1590/S0100-879X2005000400005

Simopoulos, A. P. (2008). The importance of the omega-6/omega-3 fatty acid ratio in cardiovascular disease and other chronic diseases. Exp. Biol. Med. 233, 674-688. doi: 10.3181/0711-MR-311

Simopoulos, A. P. (2016). An increase in the omega-6/omega-3 fatty acid ratio increases the risk for obesity. Nutrients 8:128. doi: 10.3390/nu8030128

Sivagnanam, S. P., Yin, S., Choi, J. H., Park, Y. B., Woo, H. C., and Chun, B. S. (2015). Biological properties of fucoxanthin in oil recovered from two brown seaweeds using supercritical CO2 extraction. Mar. Drugs 13, 3422-3442. doi: $10.3390 / \mathrm{md} 13063422$

Škrovánková, S. (2011). Seaweed vitamins as nutraceuticals. Adv. Food Nutr. Res. 64, 357-369. doi: 10.1016/B978-0-12-387669-0.00028-4

Smit, A. J. (2004). Medicinal and pharmaceutical uses of seaweed natural products: a review. J. Appl. Phycol. 16, 245-262. doi: 10.1023/B:JAPH.0000047783.36 600.ef

Solibami, V. J., and Kamat, S. Y. (1985). Distribution of tocopheral (vitamin E) in marine algae from Goa, West Coast of India. Indian J. Mar. Sci. 14, 228-229.

Song, M. Y., Ku, S. K., and Han, J. S. (2012). Genotoxicity testing of low molecular weight fucoidan from brown seaweeds. Food Chem. Toxicol. 50, 790-796. doi: 10.1016/j.fct.2011.11.010

Song, S., Peng, H., Wang, Q., Liu, Z., Dong, X., Wen, C., et al. (2020). Inhibitory activities of marine sulfated polysaccharides against SARS-CoV-2. Food Funct. 11, 7415-7420. doi: 10.1039/D0FO02017F

Stiger-Pouvreau, V., Bourgougnon, N., and Deslandes, E. (2016). "Carbohydrates from seaweeds," in Seaweed in health and disease prevention, eds J. Fleurence and I. Levine (Cambridge: Academic press), 223-274. doi: 10.1016/B978-0-12802772-1.00008-7

Sugiura, Y., Matsuda, K., Okamoto, T., Kakinuma, M., and Amano, H. (2008). Anti-allergic effects of the brown alga Eisenia arborea on Brown Norway rats. Fish. Sci. 74:180. doi: 10.1111/j.1444-2906.2007.01508.x

Sultana, V., Baloch, G. N., Ara, J., Ehteshamul-Haque, S., Tariq, R. M., and Athar, M. (2012). Seaweeds as an alternative to chemical pesticides for the management of root diseases of sunflower and tomato. J. Appl. Bot. Food Qual. $84: 162$.

Sun, Y., Chen, X., Liu, S., Yu, H., Li, R., Wang, X., et al. (2018). Preparation of low molecular weight Sargassum fusiforme polysaccharide and its anticoagulant activity. J. Oceanol. Limnol. 36, 882-891. doi: 10.1007/s00343-018-7089-6

Tabarsa, M., Rezaei, M., Ramezanpour, Z., and Waaland, J. R. (2012). Chemical compositions of the marine algae Gracilaria salicornia (Rhodophyta) and Ulva lactuca (Chlorophyta) as a potential food source. J. Sci. Food Agric. 92, 2500-2506. doi: 10.1002/jsfa.5659

Tamama, K. (2020). Potential benefits of dietary seaweeds as protection against COVID-19. Nutr. Rev. 79, 814-823. doi: 10.1093/nutrit/nuaa126

Tan, B. L., and Norhaizan, M. E. (2019). Carotenoids: how effective are they to prevent age-related diseases? Molecules 24:1801. doi: 10.3390/ molecules 24091801

Tanna, B., Brahmbhatt, H. R., and Mishra, A. (2019). Phenolic, flavonoid, and amino acid compositions reveal that selected tropical seaweeds have the 
potential to be functional food ingredients. J. Food Process. Preserv. 43:e14266. doi: $10.1111 /$ jfpp. 14266

Tanna, B., Yadav, S., and Mishra, A. (2020). Anti-proliferative and ROS-inhibitory activities reveal the anticancer potential of Caulerpa species. Mol. Biol. Rep. 47, 7403-7411. doi: 10.1007/s11033-020-05795-8

Tanna, B., and Mishra, A. (2018a). Metabolites unravel nutraceutical potential of edible seaweeds: an emerging source of functional food. Compr. Rev. Food Sci. Food Saf. 17, 1613-1624. doi: 10.1111/1541-4337.12396

Tanna, B., and Mishra, A. (2018b). "Metabolomics of seaweeds: tools and techniques," in Plant metabolites and regulation under environmental stress, eds P. Ahmad, M. A. Ahanger, V. P. Singh, D. K. Tripathi, P. Alam, (Cambridge: Academic Press), 37-52. doi: 10.1016/B978-0-12-812689-9.00002-9

Tanna, B., and Mishra, A. (2019). Nutraceutical potential of seaweed polysaccharides: structure, bioactivity, safety, and toxicity. Compr. Rev. Food Sci. Food Saf. 18, 817-831. doi: 10.1111/1541-4337.12441

Tseng, C. K. (2001). Algal biotechnology industries and research activities in China. J. Appl. Phycol. 13, 375-380. doi: 10.1023/A:1017972812576

Vaillant, A. A. J., Vashisht, R., and Zito, P. M. (2020). Immediate Hypersensitivity Reactions. In StatPearls [Internet]. Florida: StatPearls Publishing.

Vallinayagam, K., Arumugam, R., Kannan, R. R. R., Thirumaran, G., and Anantharaman, P. (2009). Antibacterial activity of some selected seaweeds from Pudumadam coastal regions. Glob. J. Pharmacol. 3, 50-52.

van Dooremalen, C., Pel, R., and Ellers, J. (2009). Maximized PUFA measurements improve insight in changes in fatty acid composition in response to temperature. Arch. Insect Biochem. Physiol. 72, 88-104. doi: 10.1002/arch.20325

Vasconcelos, J. B., de Vasconcelos, E. R., Urrea-Victoria, V., Bezerra, P. S., Reis, T. N., Cocentino, A. L., et al. (2019). Antioxidant activity of three seaweeds from tropical reefs of Brazil: potential sources for bioprospecting. J. Appl. Phycol. 31, 835-846. doi: 10.1007/s10811-018-1556-5

Vásquez, V., Martínez, R., and Bernal, C. (2019). Enzyme-assisted extraction of proteins from the seaweeds Macrocystispyrifera and Chondracanthuschamissoi: characterization of the extracts and their bioactive potential. J. Appl. Phycol. 31, 1999-2010. doi: 10.1007/s10811-018-1712-y

Venkatesan, M., Arumugam, V., Pugalendi, R., Ramachandran, K., Sengodan, K., Vijayan, S. R., et al. (2019). Antioxidant, anticoagulant and mosquitocidal properties of water soluble polysaccharides (WSPs) from Indian seaweeds. Process Biochem. 84, 196-204. doi: 10.1016/j.procbio.2019.05.029

Ventola, C. L. (2015). The antibiotic resistance crisis: part 1: causes and threats. Pharm. Ther. 40:277.

Vidanarachchi, J. K., Iji, P. A., Mikkelsen, L. L., Sims, I., and Choct, M. (2009). Isolation and characterization of water-soluble prebiotic compounds from Australian and New Zealand plants. Carbohydr. Polym. 77, 670-676. doi: 10. 1016/j.carbpol.2009.02.009

Vijayabaskar, P., and Shiyamala, V. (2012). Antioxidant properties of seaweed polyphenol from Turbinaria ornata (Turner) J. Agardh, 1848. Asian Pac. J. Trop. Biomed. 2, S90-S98. doi: 10.1016/S2221-1691(12)60136-1

Wang, L., Jayawardena, T. U., Yang, H. W., Lee, H. G., Kang, M. C., Sanjeewa, K. K., et al. (2020). Isolation, Characterization, and Antioxidant Activity Evaluation of a Fucoidan from an Enzymatic Digest of the Edible Seaweed, Hizikia fusiforme. Antioxidants 9:363. doi: 10.3390/antiox9050363

Wang, S., Wang, W., Hou, L., Qin, L., He, M., Li, W., et al. (2020). A sulfated glucuronorhamnan from the green seaweed Monostroma nitidum: characteristics of its structure and antiviral activity. Carbohydr. Polym. 227:115280. doi: 10.1016/j.carbpol.2019.115280

Wang, T., Jonsdottir, R., and Ólafsdóttir, G. (2009). Total phenolic compounds, radical scavenging and metal chelation of extracts from Icelandic seaweeds. Food Chem. 116, 240-248. doi: 10.1016/j.foodchem.2009.02.041

Wang, W., Wang, S. X., and Guan, H. S. (2012). The antiviral activities and mechanisms of marine polysaccharides: an overview. Mar. Drugs 10, 27952816. doi: $10.3390 / \mathrm{md} 10122795$

Watanabe, F., Takenaka, S., Katsura, H., Masumder, S. Z. H., Abe, K., Tamura, Y., et al. (1999). Dried green and purple lavers (Nori) contain substantial amounts of biologically active vitamin B12 but less of dietary iodine relative to other edible seaweeds. J. Agric. Food Chem. 47, 2341-2343. doi: 10.1021/ jf981065c

Weinstein, B., Rold, T. L., Harrell, C. E. Jr., Burns, M. W. III, and Waaland, J. R. (1975). Reexamination of the bromophenols in the red alga Rhodomela larix. Phytochemistry 14, 2667-2670. doi: 10.1016/0031-9422(75)85247-2

Wells, M. L., Potin, P., Craigie, J. S., Raven, J. A., Merchant, S. S., Helliwell, K. E., et al. (2017). Algae as nutritional and functional food sources: revisiting our understanding. J. Appl. Phycol. 29, 949-982. doi: 10.1007/s10811-0160974-5

Wijesekara, I., and Kim, S. K. (2010). Angiotensin-I-converting enzyme (ACE) inhibitors from marine resources: prospects in the pharmaceutical industry. Mar. Drugs 8, 1080-1093. doi: 10.3390/md8041080

Wijesinghe, W. A. J. P., Athukorala, Y., and Jeon, Y. J. (2011a). Effect of anticoagulative sulfated polysaccharide purified from enzyme-assistant extract of a brown seaweed Ecklonia cava on Wistar rats. Carbohydr. Polym. 86, 917-921. doi: 10.1016/j.carbpol.2011.05.047

Wijesinghe, W. A. J. P., Ko, S. C., and Jeon, Y. J. (2011b). Effect of phlorotannins isolated from Ecklonia cava on angiotensin I-converting enzyme (ACE) inhibitory activity. Nutr. Res. Pract. 5, 93-100. doi: 10.4162/nrp.2011.5.2.93

Woo, M. N., Jeon, S. M., Shin, Y. C., Lee, M. K., Kang, M. A., and Choi, M. S. (2009). Anti-obese property of fucoxanthin is partly mediated by altering lipidregulating enzymes and uncoupling proteins of visceral adipose tissue in mice. Mol. Nutr. Food Res. 53, 1603-1611. doi: 10.1002/mnfr.200900079

Yan, X., Yang, C., Lin, G., Chen, Y., Miao, S., Liu, B., et al. (2019). Antidiabetic potential of green seaweed Enteromorpha prolifera flavonoids regulating insulin signaling pathway and gut microbiota in type 2 diabetic mice. J. Food Sci. 84, 165-173. doi: 10.1111/1750-3841.14415

Yang, C., Chen, Y., Chen, M., Jia, R., Liu, B., and Zhao, C. (2017). The antidiabetic activity of brown seaweed Sargassum confusum polysaccharide hydrolysates in insulin resistance HepG2 cells in vitro. Res. J. Biotechnol. 12, 1-9.

Yang, C. F., Lai, S. S., Chen, Y. H., Liu, D., Liu, B., Ai, C., et al. (2019). Antidiabetic effect of oligosaccharides from seaweed Sargassum confusum via JNKIRS1/PI3K signalling pathways and regulation of gut microbiota. Food Chem. Toxicol. 131:110562. doi: 10.1016/j.fct.2019.110562

Yoon, M., and Cho, S. (2018). Triphlorethol A, a Dietary Polyphenol from Seaweed, Decreases Sleep Latency and Increases Non-Rapid Eye Movement Sleep in Mice. Mar. Drugs 16:139. doi: 10.3390/md16050139

Yoshioka, H., Ishida, M., Nishi, K., Oda, H., Toyohara, H., and Sugahara, T. (2014). Studies on anti-allergic activity of Sargassum horneri extract. J. Funct. Foods 10, 154-160. doi: 10.1016/j.jff.2014.06.002

Zenthoefer, M., Geisen, U., Hofmann-Peiker, K., Fuhrmann, M., Kerber, J., Kirchhöfer, R., et al. (2017). Isolation of polyphenols with anticancer activity from the Baltic Sea brown seaweed Fucus vesiculosus using bioassay-guided fractionation. J. Appl. Phycol. 29, 2021-2037. doi: 10.1007/s10811-017-1080-z

Zhang, J., Tiller, C., Shen, J., Wang, C., Girouard, G. S., Dennis, D., et al. (2007). Antidiabetic properties of polysaccharide-and polyphenolic-enriched fractions from the brown seaweed Ascophyllum nodosum. Can. J. Physiol. Pharmacol. 85, 1116-1123. doi: 10.1139/Y07-105

Zhang, X., Cao, D., Sun, X., Sun, S., and Xu, N. (2019). Preparation and identification of antioxidant peptides from protein hydrolysate of marine alga Gracilariopsis lemaneiformis. J. Appl. Phycol. 31, 2585-2596. doi: 10.1007/ s10811-019-1746-9

Zhao, C., Yang, C., Chen, M., Lv, X., Liu, B., Yi, L., et al. (2018). Regulatory efficacy of brown seaweed Lessonia nigrescens extract on the gene expression profile and intestinal microflora in type 2 diabetic mice. Mol. Nutr. Food Res. 62:1700730. doi: 10.1002/mnfr.201700730

Zuo, T., Li, X., Chang, Y., Duan, G., Yu, L., Zheng, R., et al. (2015). Dietary fucoidan of Acaudina molpadioides and its enzymatically degraded fragments could prevent intestinal mucositis induced by chemotherapy in mice. Food Funct. 6, 415-422. doi: 10.1039/c4fo00567h

Conflict of Interest: The authors declare that the research was conducted in the absence of any commercial or financial relationships that could be construed as a potential conflict of interest.

Publisher's Note: All claims expressed in this article are solely those of the authors and do not necessarily represent those of their affiliated organizations, or those of the publisher, the editors and the reviewers. Any product that may be evaluated in this article, or claim that may be made by its manufacturer, is not guaranteed or endorsed by the publisher.

Copyright (c) 2021 Choudhary, Chauhan and Mishra. This is an open-access article distributed under the terms of the Creative Commons Attribution License (CC BY). The use, distribution or reproduction in other forums is permitted, provided the original author(s) and the copyright owner(s) are credited and that the original publication in this journal is cited, in accordance with accepted academic practice. No use, distribution or reproduction is permitted which does not comply with these terms. 